\title{
SCIENTOMETRIC REVIEW OF CONSTRUCTION PROJECT SCHEDULE STUDIES: TRENDS, GAPS AND POTENTIAL RESEARCH AREAS
}

\author{
Gebrehana DERBE®1, Yashuai LI®1,2, Di WU®³ ${ }^{3}$, Qiuhong ZHAO®1, ${ }^{*}$ \\ ${ }^{1}$ School of Economics and Management, Beihang University, Haidian District, 100191 Beijing, China \\ ${ }^{2}$ Beijing Key Laboratory of Emergency Support Simulation Technologies for City Operations, 100091 Beijing, \\ China \\ ${ }^{3}$ Transport Planning and Research Institute, Ministry of Transport, Building 2, Shuguangxili A6, Chaoyang \\ District, 100028 Beijing, China \\ ${ }^{4}$ Beijing International Science and Technology Cooperation Base for City Safety Operation and Emergency \\ Support, 100191 Beijing, China
}

Received 08 September 2019; accepted 25 November 2019

\begin{abstract}
Scheduling plays a fundamental role in construction projects' success and thus has drawn attention from both academic researchers and industry practitioners. A large number of research articles tend to solve emerging challenges in construction project schedule (CPS). Therefore, there is a strong need of systematic review on existing studies. In this study, a total of 332 articles were retrieved from Scopus database using title, abstract and keywords with respect to CPS and filtered by document type, language type and abstract content. In particular, science mapping approach was adopted to analyse selected journal articles. These articles were examined using three sequential processes, including bibliometric search, scientometric analysis, and in-depth qualitative discussion. It could demonstrate the most influential journals, researchers, published articles, and active countries/regions in this area. In addition, major CPS knowledge areas were identified and summarized as CPS constructability, applications of variety of CPS methods, CPS optimization models and algorithms, identification and quantification of schedule risks and uncertainties, CPS performance management, and adopting new emerging CPS technologies and methods. Furthermore, knowledge gaps and future potential research directions were also discussed in detail. Finally, a comprehensive CPS framework was proposed as a sound reference in future research.
\end{abstract}

Keywords: construction project schedule (CPS), scheduling methods, schedule uncertainties, resource-constrained scheduling, schedule optimization, scientometric analysis, bibliometric.

\section{Introduction}

Developing a robust construction project schedule (CPS) is one of the major factors towards of construction projects' success. However, meeting project schedule is being challenged due to a number of factors such as project schedule reliability (Gannon et al., 2012), choice of CPS methods (Abou-Ibrahim et al., 2019; Al Nasseri et al., 2016; Xu et al., 2018), complexity of projects (Abou-Ibrahim et al., 2019), probable existence of schedule risks and risk prediction capability (Choudhry et al., 2014; Liu et al., 2015; Luu et al., 2009; Shen et al., 2017; Soto Ramírez et al., 2018), project finance (Larsen et al., 2016), extent of project team collaboration (Sinesilassie et al., 2017) and other factors. Previous studies (Bakry et al., 2016; Ghoddousi et al., 2017; Russell et al., 2013, 2014) indicated that providing management reserve (such as providing an allowable buffer time) helps to manage prominent risks and uncertainties. As stated in Poshdar et al. $(2016,2018)$, reasonable amount of buffer can be estimated using early start and finish time of each activity. Moreover, increased emphasis on planning effort by practitioners contributes to develop reliable CPS (Lekshmi \& Unnikrishnan, 2018; Lines et al., 2015). Recently, researchers have been focusing on emerging technologies such as four dimensional building information modeling (4D-BIM) which links 3D geometrical design with project schedule (Chan et al., 2015).

Scholars have published a large number of papers in worldwide recognized peer-reviewed journals in wide areas of CPS research including advancement of CPS meth-

*Corresponding author. E-mail: qhzhao@buaa.edu.cn 
ods (e.g., BIM) (Mirzaei et al., 2018; Wang \& Rezazadeh Azar, 2019), CPS optimization (e.g., resource constrained schedule optimization) (García-Nieves et al., 2018; Giran et al., 2017), time-cost-trade off analysis and CPS crashing (Gwak et al., 2016; Moselhi \& Alshibani, 2013), CPS control (Tang et al., 2014) and schedule control. Some researchers have conducted reviews on specific CPS topics, which are summarized in Table 1. For instance, Ballesteros-Pérez et al. (2019) have examined non-linear time and cost trade-off analysis using previous literature and developed a genetic algorithm model with combined application of activity crashing and fast-tracking for CPS compression of construction projects. Yang (2017) has conducted a review that the total float was the most commonly used for schedule management which may lead to non-realistic management of floats and provide strategies for classifying and understanding of floats as an alternative float management. As stated in Al Nasseri et al. (2016), using unstructured review, selection of CPS methods or combination of methods needs to consider multidimensional aspects such as usability, size and complexity of a project. Bragadin and Kähkönen (2016) have developed a schedule quality assessment model based on identified schedule attributes such as construction process, schedule mechanics, and CPS control process. Furthermore, Vidhyasri and Sivagamasundari (2017) have examined 40 relevant articles to identify factors affecting CPS including planning and controlling system, climate conditions, and resource availability.

Using the guide developed by Dochy (2006), review papers can be classified as "integrative", "critique" and "state-of-the-art":

1. Integrative reviews provide comprehensive summaries on outcome of related previous papers.

2. Critique provides critical judgments based on subject matter of papers.

3. State-of-the-art considers the most current research papers.

As shown in Table 1, lack of systematically peer-reviewed publications has been noticed. Despite previous peer-reviewed papers' contribution on specific CPS topics, the following limitations are noticed: (1) they addressed specific topics that may had biased tendency due to manual review; (2) all of them were integrative and critique reviews that have a tendency of subjectivity and thus may be lack of new perspectives; (3) no peer-reviewed papers

Table 1. Summary of previous peer-reviewed review articles

\begin{tabular}{|c|c|c|c|c|c|c|}
\hline $\begin{array}{l}\text { Researcher } \\
\text { (1) }\end{array}$ & $\begin{array}{l}\text { Review } \\
\text { type } \\
(2)\end{array}$ & \begin{tabular}{|} 
Review method \\
and tools \\
(3)
\end{tabular} & $\begin{array}{l}\text { Study } \\
\text { period } \\
(4)\end{array}$ & $\begin{array}{c}\text { Database } \\
\text { sources } \\
(5)\end{array}$ & $\begin{array}{l}\text { Focus of study } \\
\text { (6) }\end{array}$ & $\begin{array}{l}\text { Study finding } \\
\text { (7) }\end{array}$ \\
\hline $\begin{array}{l}\text { Ballesteros-Pérez } \\
\text { et al. (2019) }\end{array}$ & Integrative & Manual & $1961-2019$ & - & $\begin{array}{l}\text { Fast tracking based schedule } \\
\text { compression for projects } \\
\text { having non-linear time and } \\
\text { cost relationship }\end{array}$ & $\begin{array}{l}\text { Fast tracking model for } \\
\text { both renewable and non- } \\
\text { renewable resources }\end{array}$ \\
\hline Zareei (2018) & Integrative & Manual & - & - & $\begin{array}{l}\text { CPS methods for large scale } \\
\text { biogas projects and having } \\
\text { interdependent activities } \\
\text { with varying duration }\end{array}$ & $\begin{array}{l}\text { Adopted typical network } \\
\text { diagram based CPM } \\
\text { method }\end{array}$ \\
\hline Yao et al. (2018) & Integrative & Manual & - & - & $\begin{array}{l}\text { Optimization of multiple } \\
\text { objective scheduling for } \\
\text { construction projects }\end{array}$ & $\begin{array}{l}\text { Heuristic, metaheuristic } \\
\text { and mathematical models }\end{array}$ \\
\hline Yang (2017) & Critique & Manual & - & - & $\begin{array}{l}\text { Strategies for classifying } \\
\text { and understanding of float } \\
\text { management }\end{array}$ & $\begin{array}{l}\text { Five managerial essentials } \\
\text { and three proactive } \\
\text { strategies }\end{array}$ \\
\hline $\begin{array}{l}\text { Vidhyasri and } \\
\text { Sivagamasundari } \\
\text { (2017) }\end{array}$ & Critique & Manual & $1992-2017$ & $\begin{array}{l}40 \text { papers } \\
\text { with un } \\
\text { specified } \\
\text { database }\end{array}$ & $\begin{array}{l}\text { Factors affecting } \\
\text { performance of CPS }\end{array}$ & $\begin{array}{l}\text { Identifies top factors such } \\
\text { as resource availability, } \\
\text { weather, and regulations. }\end{array}$ \\
\hline $\begin{array}{l}\text { Al Nasseri et al. } \\
(2016)\end{array}$ & Integrative & Manual & $1956-2016$ & - & $\begin{array}{l}\text { Choice of CPS methods } \\
\text { to enhance success of } \\
\text { construction projects }\end{array}$ & $\begin{array}{l}\text { Provide taxonomy of CPS } \\
\text { methods }\end{array}$ \\
\hline $\begin{array}{l}\text { Bragadin and } \\
\text { Kähkönen (2016) }\end{array}$ & integrative & Manual & - & - & $\begin{array}{l}\text { CPS health assessment using } \\
\text { schedule requirements }\end{array}$ & CPS assessment model \\
\hline $\begin{array}{l}\text { Faghihi et al. } \\
(2015)\end{array}$ & Integrative & Manual & 1985-2014 & - & $\begin{array}{l}\text { Artificial intelligence for CPS } \\
\text { automation }\end{array}$ & $\begin{array}{l}\text { Model-based, expert } \\
\text { systems, case-based } \\
\text { reasoning, genetic } \\
\text { algorithm }\end{array}$ \\
\hline Zhou et al. (2013) & Integrative & Manual & - & - & Optimization of CPS & $\begin{array}{l}\text { Heuristic methods CPS } \\
\text { optimization }\end{array}$ \\
\hline $\begin{array}{l}\text { Yahya and } \\
\text { Mohamad (2011) }\end{array}$ & Critique & Manual & - & - & $\begin{array}{l}\text { Enabling rapid construction } \\
\text { via lean principle }\end{array}$ & $\begin{array}{l}\text { Eight enablers to integrate } \\
\text { with lean }\end{array}$ \\
\hline
\end{tabular}


were systematically and logically structured. Thus, it is imperative to systematically review the state of art of CPS researches in order to understand the status of research trends, identify research gaps, provide future directions and identify accepted practices as well.

Construction project schedule is one of the requirements of successful construction project management. It plays a significant role in determining the flexibility with the available resources and complex precedence relationships, and thus becomes a substantial challenge worldwide. Though a lot of academic researchers and industry practitioners paid attentions to it in the last few decades, there still exist a large number of project failure associated with project scheduling. Researchers have investigated problems concerning with CPS's reliability, methods, causing factors and risks, resource assignment and CPS emerging technologies. However, there is a strong need of systematic review on existing studies of last decade (2009-2019). Thus, a comprehensive review state-of-theart of CPS would be relevant to provide holistic picture for practitioners and researchers via systematic and science mapping approach.

This research paper aims to review CPS papers to serves as a basis for practitioners and researchers for further discussions on both undergoing and new research topics. In order to achieve the objectives, this paper is structured as follows. Section 1 presents methodology about science mapping approach and further qualitative discussion. Section 2 states initial results through science mapping approach. Section 3 shows the extended science mapping approach to further discuss the research topics, research gaps, and trends in CPS. Finally, conclusions are drawn.

\section{Research methodology}

In order to conduct a comprehensive review, it is crucial to follow a systematical methodology. This study adopted science mapping approach to develop a bibliometric map based on the Scopus database sources between 2009 and 2019 regarding construction project scheduling. Figure 1 shows the steps of the review framework and processes, which include a bibliometric search, a scientometric data analysis and a detailed discussion of analysis results.

\subsection{Bibliometric search data collection}

A bibliometric search provides sufficient information of necessary records (Bankar \& Lihitkar, 2019). Google Scholar (GS), Scopus and Web of Science (WoS) have been widespread database sources (Bakkalbasi et al., 2006). GS found the largest percentage of citations, and indexed any document that has an academic structure (Martín-Martín et al., 2018). This usually leads to inconsistent result (Falagas et al., 2008). GS might also lead to double citation counts, reporting higher citations than the reality when

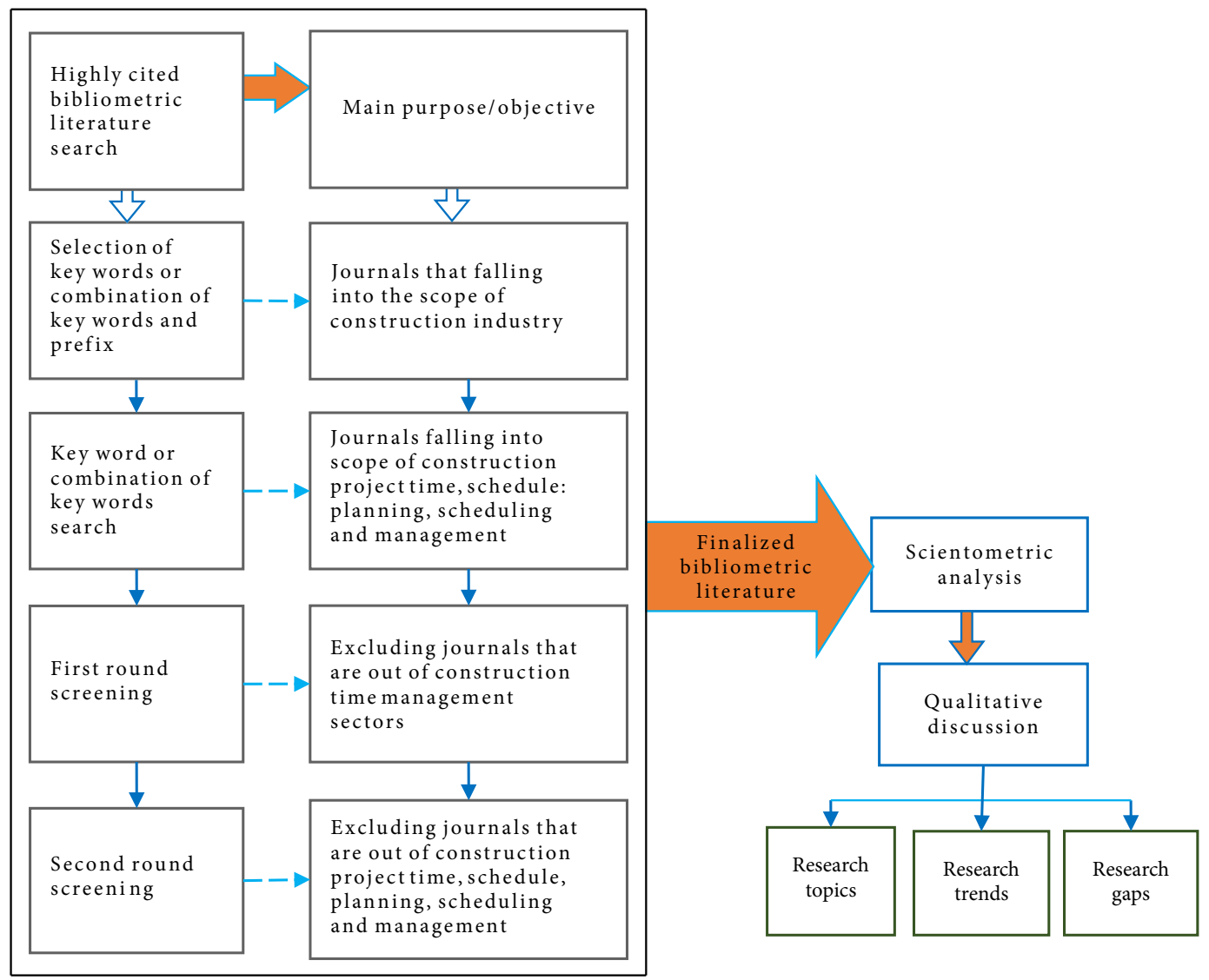

Figure 1. The methodological process 
two or more versions of same journal articles are found online (Jacsó, 2005). Accordingly, citations found in GS need some substantial process to identify and clarify between double citation counts and homonyms (documents that look alike). Thus, incidental mistakes on citations in GS are subjected to errors. These might have major impact on citation metrics which lead to inconsistent result. However, Scopus indexed journal articles have no such type of problems, and articles are not subjected to double citation counting. Thus, citations of documents from Scopus are more reliable than GS. Meho and Yang (2006) indicated that citations in GS usually helpful for seeking an academic position or research grants. Moreover, if there is no problem of double citation counts in GS, the higher number of citations in this database could not change the ranking of most cited documents compared to Scopus (Meho \& Yang, 2006). For instance, in this study, research conducted by Luu et al. (2009) ("Quantification of schedule risks using belief network in construction projects") has been ranked first in both Scopus and GS with 98 and 209 citations respectively. Similarly, an article conducted by Li and Zhang (2013) has been ranked last in both Scopus and GS with 35 and 17 citations. It is more reliable that citations in Scopus are consistent to rank documents in comparison to GS.

Moreover, Scopus and WoS have higher academic contribution by focusing on selective scientific journal articles (Aghaei Chadegani et al., 2013; Martín-Martín et al., 2018). In addition to this, GS have less coverage in engineering and natural sciences compared to Scopus and WoS; and there exist a higher percentage of overlap with GS in this subject category (Martín-Martín et al., 2018). In this study, 1224 and 1152 journal articles have been searched from GS and Scopus respectively. There are a total of 1092 articles are the same from the both, which accounts for $94.8 \%(1092 / 1152)$. After the preliminary screening, more papers fall in the CPS from Scopus rather than that from GS. In particular, a number of documents indexed by GS are not open accessed. Moreover, Scopus covers a wider range of more recent publications than web of science (Aghaei Chadegani et al., 2013). Thus, to balance the academic contribution and coverage, this study used bibliometric search of the Scopus database engine, which is one of the largest source of peer-reviewed literature comprising of the largest number of citations and abstracts (Bakkalbasi et al., 2006; Martín-Martín et al., 2018). Furthermore, open access articles that are found only in GS have been retrieved and used in this study when they are necessary. In order to do a comprehensive review, the following data collection procedures have been followed: (1) literature search for highly-cited research papers on the topic of construction planning and scheduling to determine the related searching key words. Many search items, in this stage, include publications of other sectors than construction due to the reason that the term "planning" and "scheduling" are commonly used in many domain areas. Also, most of the search items in the construction industry cover large domain area instead of more specific to project schedule; (2) combining the most important pre-fix search terms "construction project" (since construction schedules are usually prepared in project basis) with the term "planning" or "scheduling" or both after reviewing preliminary research publications in the first procedure to search CPS related literature; and (3) bibliometric search was conducted using combination of title, abstract and keyword search code in the domain of CPS as follows: TITLE-ABS-KEY ("construction project" schedule) OR TITLE-ABS-KEY ("construction project" planning) OR TITLE-ABS-KEY ("construction project" scheduling) OR TITLE-ABS-KEY ("construction project" "planning and scheduling") OR TITLE-ABS KEY ("construction project time") OR TITLE-ABS-KEY ("construction project schedule" management) OR TITLE-ABS KEY ("construction project time" management).

During the searching, English publication language was chosen and journal articles were selected as journal papers, which usually provide more theoretic contributions compared to others including conference papers. The publication articles chosen were from the years 2009 to 2019 since wide attention of CPS was given in 2009 as shown in the Figure 2. In order to exclude articles having no related abstract with CPS, manual review was conducted to identify domain areas of CPS papers before going on to analyze the retrieved bibliographic data. After careful and repetitive manual review of papers, 332 research articles were ultimately retrieved for further scientometric analysis.

\subsection{Scientometric data analysis}

Manual review of such a number of research publications is time consuming and less reliable due to its subjectivity. In this paper, scientometric data analysis was adopted for systematic review of bibliometric literatures (Cobo et al., 2011). VOSViewer, a scientometric analysis software tool, was chosen to construct and analyze bibliometric network of science due to its special mining and visualization feature for large amounts of textual data (Van Eck \& Waltman, 2011). Furthermore, there are a number of extant studies that have used VOSViewer in the field of construction management, i.e., construction waste management (Jin et al., 2019a), construction safety (Jin et al., 2019b) and building information modeling (He et al., 2017). VOSViewer scientometric analysis is a distance-based bibliometric network visualization between nodes to identify the extent of the relation on the network (Van Eck \& Waltman, 2014). For the analysis, retrieved bibliographic publications were exported with all essential information records including titles, abstracts, and keywords, number of citations, sources, authors, institutions and references which are relevant for creation of bibliometric network. In this study, VOSViewer was applied to: (1) load 332 journal articles (i.e., an input data) with CSC format file that have been downloaded from Scopus; (2) create, visualize and analyze bibliometric networks to identify influential 
researchers, publication papers, and journals; and (3) map and analyze the trends of research topics using bibliometric network of words in the domain of CPS.

The analysis is done based on the output of the data mining software (i.e., VOSViewer), which have been used in many literature reviewing articles. Thus, inspired by the capability of VOSViewer to extract the textual information of bibliometric data and to construct bibliometric network (Van Eck \& Waltman, 2011), 332 journal articles (inputs) are loaded into VOSViewer. The textual information of these articles is extracted and visualized through bibliometric networks such as "citation-documents", "co-occurrence-author key words", and "citation-authors" to identify the most cited articles, studied topics, and influential authors respectively in the domain of CPS during the last decade. Articles' different information could be visualized in different bibliometric networks when the textual information of journal articles has a strong relationship with the subject matter. For instance, journal articles with high citation number might be frequently studied topic or they might be from an influential country or region in the area of that topic. Thus, they could be cited in various sections of this paper and might be used redundantly if they are influential with regard to various aspects. In this regard, journal articles from 332 input data might not be used and cited in this paper if their textual information is extracted and visualized in the bibliometric network due to their limitation regarding the subject matter. Thus, among the 332 journal articles, only relevant articles related to the subject matter are used and cited to support the discussion of CPS topics and subtopics where they are necessary.

\subsection{Qualitative discussion}

Detailed qualitative discussion was also provided based on scientometric analysis to summarize the mainstream of research, identify existed research gaps and propose future directions in CPS research. Finally, comprehensive framework connecting mainstream research trends with future research areas is proposed to create clear understanding for researchers.

\section{Research analysis result}

\subsection{An overview of a bibliometric literature data}

The number of papers published from 2009 to 2019 in the domain of CPS is shown in Figure 2. The number of published papers was incomplete for 2019 as the data was collected up to April 29, 2019. However, the number of research publications shows a significant increase trend of 9 papers in 2010 to 55 papers in 2018. It indicates that the domain of CPS highly attracted the attention of many researchers in the last decade.

\subsection{Main influential journals}

The main influential journals in the area of CPS are shown in Figure 3 and Table 2. These influential journals were visualized and analysed using 'citation-documents' bibliometric network in VOSViewer. For each journal, minimum of three research papers and 30 citations were set for further analysis. Accordingly, 11 out of 111 journals met the minimum thresholds. Figure 3 shows the citation bibliometric network, in which nodes are journals and lines from one to another shows their citation relationships. It is noted that the names of journals may not be shown fully in VOSViewer and the omitted information can be seen in Table 2.

As shown in Figure 3, the size and font of journal nodes are clustered differently based on their number of published papers and citations. Journals with high number of papers and citations are larger in node and font size and journals having a mutual citation are strongly related each other (Van Eck \& Waltman, 2014). For instance, Journal of Construction Engineering and Management, Automation in Construction, and Journal of Civil Engineering and Management were the major influential journals. Other quantitative measurements of journals are summarized in Table 2.

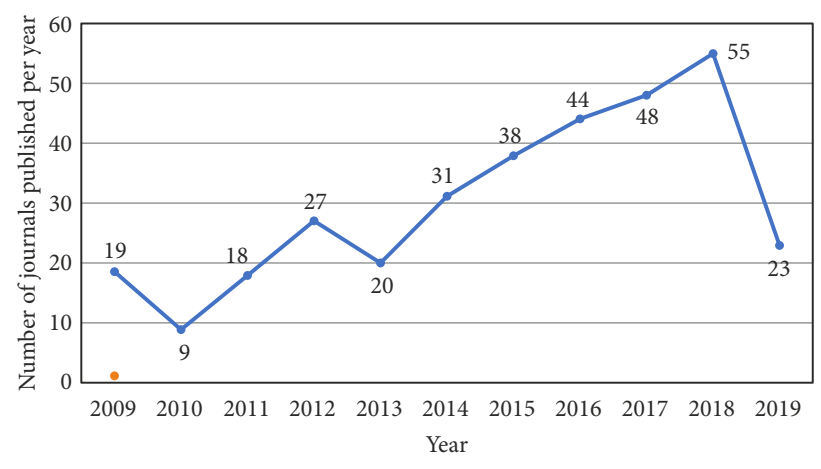

Figure 2. The trend of number of published papers per year from year 2009 to 2019

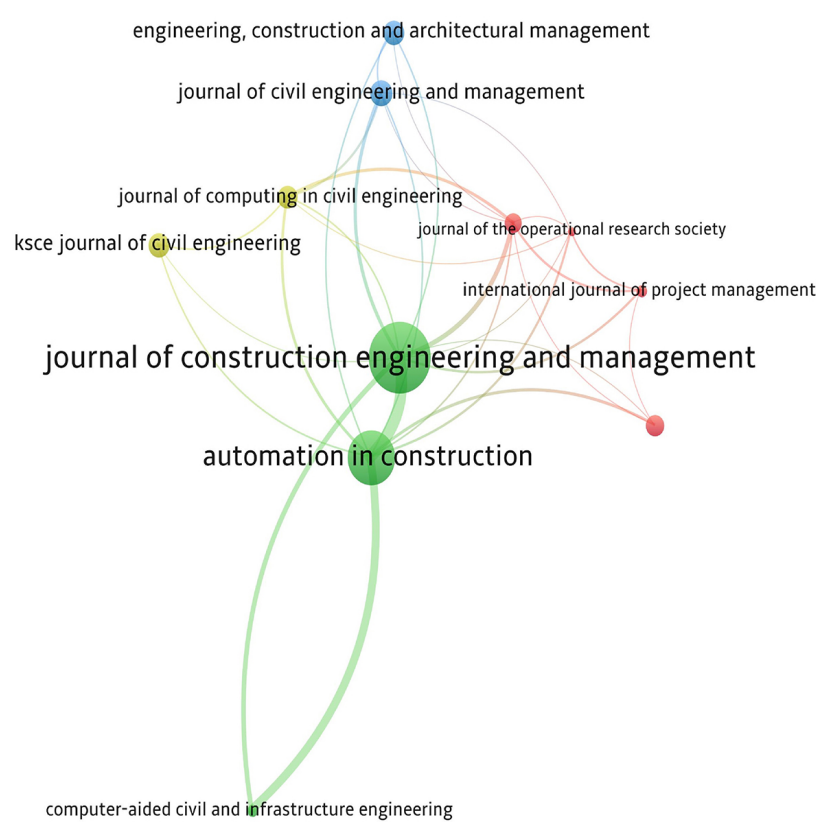

Figure 3. Science mapping of main influential journals in the domain of CPS 
Table 2. Summary of measurements of journals publishing CPS research

\begin{tabular}{|l|c|c|c|c|}
\hline \multicolumn{1}{|c|}{ Journal name } & $\begin{array}{c}\text { Number } \\
\text { of publications }\end{array}$ & Citation & $\begin{array}{c}\text { Average } \\
\text { citation }\end{array}$ & $\begin{array}{c}\text { Average normal } \\
\text { citation }\end{array}$ \\
\hline Journal of Construction Engineering and Management & 54 & 668 & 13 & 1.21 \\
\hline Automation in Construction & 37 & 598 & 16 & 2.13 \\
\hline Journal of Civil Engineering and Management & 13 & 73 & 6 & 0.64 \\
\hline Engineering, Construction and Architectural Management & 12 & 72 & 6 & 0.72 \\
\hline KSCE Journal of Civil Engineering & 12 & 31 & 3 & 0.46 \\
\hline Journal of Computing in Civil Engineering & 11 & 214 & 20 & 2.83 \\
\hline Journal of Management in Engineering & 10 & 101 & 10 & 1.56 \\
\hline Construction Management and Economics & 9 & 75 & 9 & 0.75 \\
\hline Computer-Aided Civil and Infrastructure Engineering & 5 & 35 & 7 & 2.88 \\
\hline International Journal of Project Management & 5 & 224 & 45 & 2.02 \\
\hline Journal of the Operational Research Society & 3 & 59 & 20 & 1.45 \\
\hline
\end{tabular}

Total citations, average citation, and average number of normal citation are used to measure and quantify the influence of journals in CPS researches. In particular, average number of normal citation is equal to dividing the total citation number to average citation number per year. The normalization adjusts the misconception that older articles gain ample time to have citations than more current publications (Van Eck \& Waltman, 2014). It is also used in subsequent tables to measure the influence of researchers, papers, author keywords, or countries in CPS research. Journals having small number of research papers publications may have highest average citation and average normal citations. For instance, Journal of Computing in Civil Engineering is less productive in number of publications (i.e., 11 papers) compared to Journal of Construction Engineering and Management (i.e., 54 papers), but received more average citations and normal citations. Journal of Construction Engineering and Management, and Automation in Construction have highest citations showing that they are the most influential journals in terms of productivity and contribution with an intermediate yearly influence of average citation and normal citation. Moreover, Journal of Civil Engineering and Management, and Engineering, Construction and Architectural Management are also the best journals contributing for publishing research papers but least yearly influence in terms of average citation and average normal citation in the domain of CPS. There are also other journals having highest yearly average citation but a less influence in production of research papers and contribution for research community such as International Journal of Project Management and Journal of the Operational Research Society.

\subsection{Science mapping of co-occurrence of key words}

The key words in the bibliometric network indicate major outlines of previous researches and depict main topics of intellectual teams and organizations (Van Eck \& Waltman, 2014). This study adopted science mapping of co-occurrence of words using "fractional counting" and "author key words" in VOSViewer to create bibliometric network (Hosseini et al., 2018). The minimum occurrence of major key words was set 3 times. During the initial result, 105 key words of out of 891 met the threshold, from these many general words were ignored, for example, "construction", "construction industry", "construction projects", "construction planning", "project scheduling, "scheduling", "construction management". Moreover, some other keywords with similar semantic connotations (i.e., "critical path method" versus "CPM", "building information modelling" versus "BIM") and words having exact meaning, but plurality difference (i.e., "buffer" versus "buffers", "risk" versus "risks" and "genetic algorithm" versus "genetic algorithms") are selected with higher occurrence value. Lastly, a total of 46 keywords were chosen as shown in Figure 4 and Table 3. The detailed quantitative measurement of most 37 keywords is summarized in the Table 3.

Figure 4 shows the most frequently occurred keywords represented by different nodes. These include but not limited to optimization, critical path method, resource levelling, resource allocation, uncertainty, schedule risks, and genetic algorithm. These frequently keywords are clustered differently in node size, colour and font size and interconnected by lines based on their relatedness. Figure 4 presents that lean construction and last planner, optimization and resource levelling, building information modelling and labour productivity are strongly related to each other from similar cluster. Keywords can be also be strongly related from different clusters such as resource allocation and genetic algorithm. In general, the most major keywords that have been studied in the domain of CPS are categorized as follows:

- Scheduling methods and tools: CPS methods such as Critical Path Method (CPM), Line of Balance (LOB), linear scheduling, analytical methods and network analysis have been studied in previous studies (Abbondati et al., 2016; Ali \& Elazouni, 2009; Alias \& Ismail, 2012);

- Schedule risks and uncertainties: CPS risks and uncertainties have been studied by many researchers re- 
Table 3. Summary of the most frequently occurred keywords in the domain of CPS research

\begin{tabular}{|c|c|c|}
\hline Key words & Occurrence & $\begin{array}{l}\text { Avg. year } \\
\text { published }\end{array}$ \\
\hline Optimization & 30 & 2014 \\
\hline Critical path method & 15 & 2015 \\
\hline Risk management & 14 & 2015 \\
\hline Project planning & 12 & 2014 \\
\hline Linear scheduling & 9 & 2016 \\
\hline Constraint programming & 9 & 2015 \\
\hline Genetic algorithms & 9 & 2013 \\
\hline Resource allocation & 9 & 2014 \\
\hline Uncertainty & 9 & 2015 \\
\hline Monte Carlo simulation & 8 & 2017 \\
\hline Resource levelling & 8 & 2017 \\
\hline Risk analysis & 7 & 2016 \\
\hline Lean construction & 7 & 2015 \\
\hline Network analysis & 7 & 2015 \\
\hline Last planner system & 6 & 2016 \\
\hline Fuzzy sets & 6 & 2013 \\
\hline Building information modelling & 5 & 2016 \\
\hline Time-cost-trade off & 5 & 2015 \\
\hline Schedule risks & 5 & 2016 \\
\hline Multi-objective optimization & 5 & 2015 \\
\hline Analytical techniques & 4 & 2015 \\
\hline Repetitive construction projects & 4 & 2015 \\
\hline Project planning and design & 4 & 2015 \\
\hline Primavera & 4 & 2017 \\
\hline Simulation models & 3 & 2012 \\
\hline Crashing & 3 & 2018 \\
\hline Fast tracking & 3 & 2016 \\
\hline Forecasting & 3 & 2013 \\
\hline Work flow & 3 & 2017 \\
\hline Buffer & 3 & 2014 \\
\hline $\begin{array}{l}\text { Resource constrained project } \\
\text { schedule }\end{array}$ & 3 & 2013 \\
\hline Resource utilization & 3 & 2014 \\
\hline Labor and personal issues & 3 & 2014 \\
\hline Production control & 3 & 2013 \\
\hline Project control & 3 & 2017 \\
\hline Line of balance & 3 & 2016 \\
\hline Linear programming & 3 & 2017 \\
\hline
\end{tabular}

Note: Keywords are listed based on their occurrence value from highest to the lowest.

lated to identification, cause-effect and their analysis (Choudhry et al., 2014; Shen et al., 2017; Xu et al., 2018);

- Schedule optimization algorithms and models: A number of CPS optimization algorithms have been studied to solve multiple CPS problems, either single objective or multiple objectives, with single or multiple

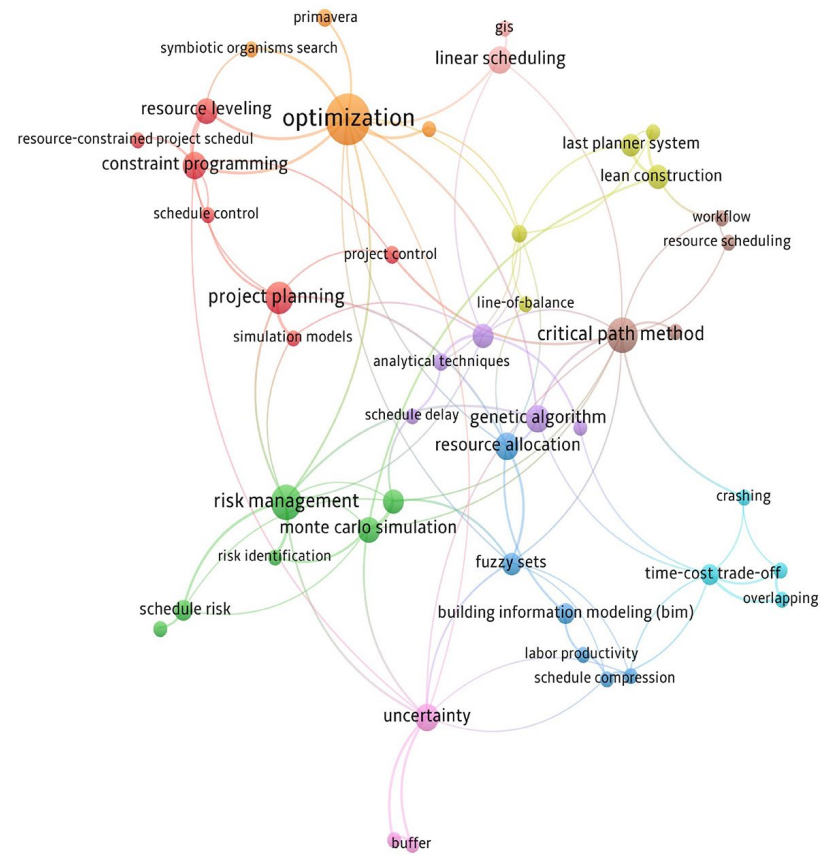

Figure 4. Bibliometric network of keywords

constraints such as genetic algorithm (Long \& Ohsato, 2009; Zou et al., 2016), fuzzy stochastic network (Radziszewska-Zielina et al., 2017), Monte Caro simulation (Indhu \& Farhan, 2015), fuzzy mathematical models (Castro-Lacouture et al., 2009), constraint programming, linear programming, and symbiotic organisms search (Cheng et al., 2016);

- CPS emerging technologies: CPS emerging technologies have been examined in previous studies such as 4D-BIM (Mirzaei et al., 2018) to detect time-space problems, geographical information system (GIS) (Bansal \& Pal, 2009) to identify logical error and missed activities, integration of BIM with primavera (Subramani \& Ammai, 2018) to manage risks and BIM schedule (Chen et al., 2011; Ding et al., 2015) to assign crew and other resources;

- Resource scheduling: One of the most research areas in CPS is to solve resource constrained scheduling problems (Christodoulou et al., 2012; Giran et al., 2017). It includes but not limited to, resource allocation (Khanzadi et al., 2016), resource levelling (ElRayes \& Jun, 2009), resource utilization (Siu et al., 2016);

- Lean project scheduling: The application of lean principle (e.g. Last Planner System (LPS)) has been widely studied to improve performance of project scheduling. For example, (Yahya \& Mohamad, 2011) studied how to apply lean for rapid work flow. The technique is applied to solve CPS constraints via team collaboration (Alsehaimi et al., 2014; Daniel et al., 2017; Kovvuri et al., 2016);

- CPS planning and management: CPS planning and controlling of CPS has been examined. For instance, early project planning is the basis of CPS (Al Nas- 
seri \& Aulin, 2016; Larsen et al., 2018) and schedule monitoring using control charts (Băncescu, 2016);

- Factors affecting schedule: CPS Labour productivity (Huang et al., 2014), resources (Larsen et al., 2016), labour and personal issues, risks and uncertainties (Kavuma et al., 2019) are examined by previous studies as they are problems affecting project schedule; and

- Time-cost-trade-off: Time-cost trade-off has been one of the most CPS research areas focusing on reduction of project duration with an optimal cost. For example, schedule compression using fast-tracking (i.e., overlapping of activities) for both linear and nonlinear projects (Ballesteros-Pérez et al., 2019) and crashing (Sonmez et al., 2016).

Table 3 shows the summary of quantitative measurements of keywords. Optimization, schedule delay, symbiotic genetic algorithms, and resource allocation have been attracting the attention of scholars. The average publication year of keywords shows their recentness in the domain of CPS. For instance, studies focusing on work flow (i.e., one of the lean principles) and building information models were mostly published recently in 2017 and 2016 respectively. The measurement result is consistence in terms of average normal citation received for production control (lean principle such as last planner), which is one of the most research theme in the areas of CPS.

\subsection{Co-authorship analysis}

Academic researchers usually collaborate with others to stimulate new ideas and to enhance their productivity (Hosseini et al., 2018). This research used "citation" and "author" to create and visualize co-authorship bibliometric network. Accordingly, the minimum number of research papers and the citations received for an author were fixed at three and 45 respectively in VOSViewer. Finally, 19 authors from 711 met the minimum thresholds. Figure 5 and Table 4 show the most influential authors who have been contributing in the areas of CPS. Most of the authors are clustered in different groups including Mohamed and EIRayes group. For example, Lucko and Cho as shown in the Figure 5 may be group members excluded due to the minimum threshold.

As shown in Table 4, authors are measured using the following five measurements: number of articles published, total citations received in Scopus, average publications per year, average citations and average normal citations. Dr. EI-Rayes is the most productive author, with having significant total citations compared to other researchers. It indicates that he is the most influential author in the last decade in CPS research. Other scholars such as Dr. Liu and Dr. Mohamed are collaborators and contributors as shown in Figure 5. Dr. Tran and Dr. Cheng are the new emerging scholars whose research publications were published in 2017 whereas Dr. EI-Rayes contributed to the research community starting in 2010 as shown in the Table 4 . The average normalized citation measurements of scholars shows the extent of authors' inspiration per year in CPS research, for example, Dr. Love, Dr. Hegazy and Dr. Wang have been attracting scholars' attention even though they were not productive in terms of the number of articles and total citations compared to other scholars.

\subsection{Citation of articles}

The most influential articles that have been published in Scopus journals were analysed using VOSViewer during the last decade. This study fixed the minimum number of citations at 30 . A total of 23 research articles from 332 articles met the minimum threshold. Figure 6 shows these most influential articles that have been published in the areas of CPS.

The detail measurement of top 15 influential research articles including scholars, research titles, received citations and average normal citations are summarized in Table 5 .

It shows the most influential research articles that received highest number of citation such as Luu et al. (2009), which has focused on quantification of schedule risks.
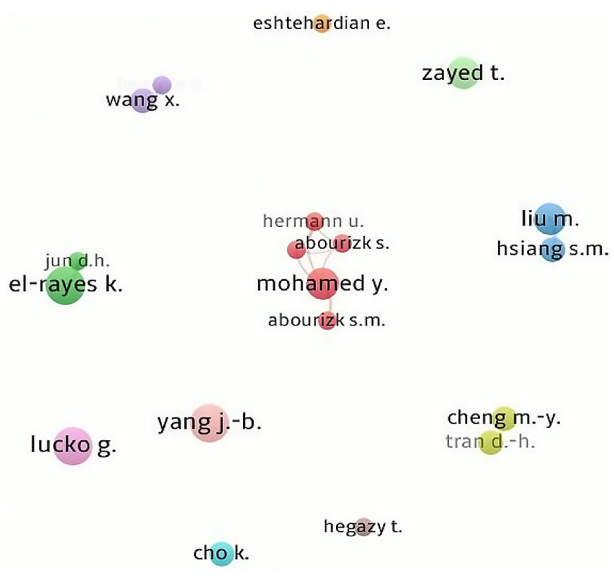

Figure 5. Co-authorship bibliometric representation Note: The full information of authors is summarized in Table 4.
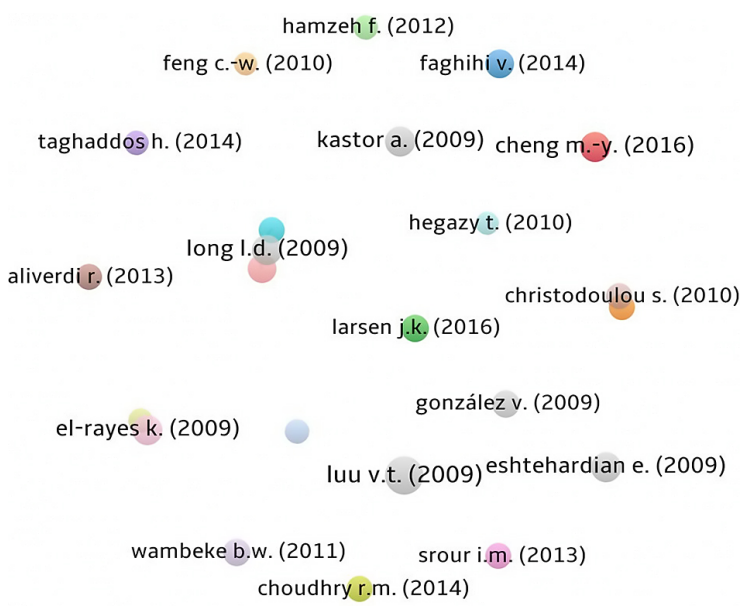

Figure 6. Mapping of most influential papers

Note: the full information of most influential research article is summarized in the Table 5. 
Table 4. Summary of measurements for co-authorship in CPS research

\begin{tabular}{|c|c|c|c|c|c|c|}
\hline Scholar & Affiliation & $\begin{array}{l}\text { Number } \\
\text { of articles }\end{array}$ & $\begin{array}{c}\text { Total } \\
\text { citations }\end{array}$ & $\begin{array}{c}\text { Average } \\
\text { publication } \\
\text { year }\end{array}$ & $\begin{array}{l}\text { Average } \\
\text { citations }\end{array}$ & $\begin{array}{c}\text { Average } \\
\text { normal } \\
\text { citations }\end{array}$ \\
\hline Khaled El-Rayes & University of Illinois at Urbana-Champaign & 6 & 124 & 2013 & 21 & 0.9 \\
\hline Dho Heon Jun & University of Illinois at Urbana-Champaign & 3 & 103 & 2010 & 34 & 1.6 \\
\hline X Wang & Curtin University & 4 & 83 & 2015 & 21 & 3.6 \\
\hline Yasser Mohamed & University of Alberta & 5 & 80 & 2014 & 16 & 1.4 \\
\hline Tarek Hegazy & University of Waterloo & 3 & 71 & 2011 & 24 & 1.6 \\
\hline Duc Hoc Tran & Ho Chi Minh City University of Technology & 4 & 68 & 2017 & 17 & 5.1 \\
\hline Ped Love & Curtin University & 3 & 64 & 2014 & 21 & 1.9 \\
\hline Min Liu & North Carolina State University & 5 & 62 & 2014 & 13 & 0.9 \\
\hline Min-Yuan Cheng & National Taiwan Univ. of Science and Technology & 4 & 62 & 2017 & 16 & 3.9 \\
\hline Simon Hsiang & Texas Tech University & 4 & 62 & 2013 & 16 & 1.1 \\
\hline Ehsan Eshtehardian & Iran University of Science and Technology & 3 & 56 & 2015 & 19 & 0.8 \\
\hline Chung-Suk Cho & Chosun University Gwangju & 4 & 54 & 2012 & 14 & 0.9 \\
\hline Hosein Taghaddos & University of Tehran & 3 & 53 & 2015 & 18 & 1.8 \\
\hline Ulrich Hermann & PCL Industrial Management Inc & 3 & 53 & 2015 & 18 & 1.8 \\
\hline Simaan AbouRizk & University of Alberta & 3 & 53 & 2014 & 18 & 1.6 \\
\hline
\end{tabular}

Note: Researchers in Table 4 are listed based on the number of total citations.

Table 5. List of publications with the highest impact in CPS

\begin{tabular}{|c|c|c|c|}
\hline Scholar & Title & $\begin{array}{l}\text { Total } \\
\text { citation }\end{array}$ & $\begin{array}{l}\text { Average normal } \\
\text { citations }\end{array}$ \\
\hline Luu et al. (2009) & $\begin{array}{l}\text { Quantifying schedule risk in construction projects using Bayesian } \\
\text { belief networks }\end{array}$ & 98 & 3.24 \\
\hline El-Rayes and Jun (2009) & Optimizing resource levelling in construction projects & 55 & 1.82 \\
\hline Eshtehardian et al. (2009) & $\begin{array}{l}\text { Fuzzy-based MOGA approach to stochastic time-cost trade-off } \\
\text { problem }\end{array}$ & 53 & 1.8 \\
\hline Kastor and Sirakoulis (2009) & $\begin{array}{l}\text { The effectiveness of resource levelling tools for Resource Constraint } \\
\text { Project Scheduling Problem }\end{array}$ & 50 & 1.65 \\
\hline Long and Ohsato (2009) & $\begin{array}{l}\text { A genetic algorithm-based method for scheduling repetitive } \\
\text { construction projects }\end{array}$ & 50 & 1.65 \\
\hline Faghihi et al. (2014) & $\begin{array}{l}\text { Construction scheduling using genetic algorithm based on building } \\
\text { information model }\end{array}$ & 45 & 3.92 \\
\hline Wambeke et al. (2011) & $\begin{array}{l}\text { Causes of variation in construction project task starting times and } \\
\text { duration }\end{array}$ & 44 & 2.70 \\
\hline González et al. (2009) & $\begin{array}{l}\text { Multi-objective design of Work-In-Process buffer for scheduling } \\
\text { repetitive building projects }\end{array}$ & 43 & 1.4 \\
\hline Larsen et al. (2016) & $\begin{array}{l}\text { Factors Affecting Schedule Delay, Cost Overrun, and Quality Level } \\
\text { in Public Construction Projects }\end{array}$ & 41 & 7.61 \\
\hline Christodoulou (2010) & $\begin{array}{l}\text { Scheduling resource-constrained projects with ant colony } \\
\text { optimization artificial agents }\end{array}$ & 38 & 3.2 \\
\hline Zhou et al. (2013) & $\begin{array}{l}\text { A review of methods and algorithms for optimizing construction } \\
\text { scheduling }\end{array}$ & 38 & 2.8 \\
\hline Choudhry et al. (2014) & $\begin{array}{l}\text { Cost and schedule risk analysis of bridge construction in Pakistan: } \\
\text { Establishing risk guidelines }\end{array}$ & 37 & 3.2 \\
\hline Aliverdi et al. (2013) & $\begin{array}{l}\text { Monitoring project duration and cost in a construction project by } \\
\text { applying statistical quality control charts }\end{array}$ & 36 & 2.65 \\
\hline Li and Zhang (2013) & $\begin{array}{l}\text { Ant colony optimization-based multi-mode scheduling under } \\
\text { renewable and non-renewable resource constraints }\end{array}$ & 35 & 2.57 \\
\hline
\end{tabular}

Note: Research articles in Table 5 are listed based on the number of publications. 
Luu et al. (2009) established cause-effect relationship between schedule risks to build Bayesian Belief Networks, an artificial intelligence tool, to represent probabilistic occurrence of variables using node and arrows to show the relationship between variables (McCabe et al., 1998). The result shows that material shortages, financial difficulties and lack of experience were the top ranked factors (Luu et al., 2009). These schedule factors are consistent with the study conducted by Choudhry et al. (2014) in Pakistan, which is ranked third article. El-Rayes and Jun (2009) and Eshtehardian et al. (2009) are the second and third ranked articles having highest total citations in the last decade respectively. The former article focused on resource levelling optimization using genetic algorithms. Eshtehardian et al. (2009) used fuzzy numbers to develop an optimized timecost-trade off via multi-objective genetic algorithms to determine the level of risk acceptance. Kastor and Sirakoulis (2009) is ranked fourth and investigated an effectiveness of resource scheduling software packages (i.e., Primavera, Microsoft Project) for construction projects having resource constraints and activity priority constraints. In general, the following research themes were the focus areas of most influential research articles but not limited to:

- Identifying causes of variation affecting activities' planned starting time and duration, including response delay regarding clarification, quality of documents, weather condition, experience (Wambeke et al., 2011) and factors affecting schedule delay such as lack of finance (Larsen et al., 2016);
- Application of buffer time to manage probable occurrence of variations (González et al., 2009);

- Using ant colony artificial neural networks for both resource constraint and non-constraint projects (Chan et al., 2015; Christodoulou, 2010);

- Resource constrained repetitive project scheduling using genetic algorithms (Long \& Ohsato, 2009) and using variety of skill workers to optimize schedule of linear projects; and

- LPS and employing new scheduling methods including BIM with genetic algorithm (Faghihi et al., 2014) and quantifying schedule risks (Luu et al., 2009).

- Adopting new scheduling methods such as BIM with genetic algorithm (Faghihi et al., 2014) and quantifying schedule risks (Luu et al., 2009) have a highest normal citation indicating that they attract the attention of research community. This indicates that one further research direction may investigate in schedule risk identification, quantification and prediction in relation to new schedule technologies.

\subsection{Active countries/regions in CPS research}

Table 6 and Figure 7 indicate the most influential countries/regions that have been active in the domain of CPS research. In VOSViewer scientometric analysis, the countries/regions with the minimum number of 4 articles and 45 citations were included. A total of 18 countries out of 58 met the threshold. In the bibliometric network, both

Table 6. Summary of most influential countries/regions in CPS research

\begin{tabular}{|c|c|c|c|c|c|}
\hline Country/Region & $\begin{array}{c}\text { Number } \\
\text { of documents }\end{array}$ & $\begin{array}{l}\text { Number } \\
\text { of Citation }\end{array}$ & $\begin{array}{c}\text { Average publication } \\
\text { year }\end{array}$ & $\begin{array}{l}\text { Average } \\
\text { citations }\end{array}$ & $\begin{array}{l}\text { Average normal } \\
\text { citations }\end{array}$ \\
\hline United States & 56 & 692 & 2014 & 13 & 1.21 \\
\hline India & 33 & 107 & 2016 & 4 & 0.5 \\
\hline Canada & 31 & 309 & 2015 & 10 & 1.2 \\
\hline China & 30 & 216 & 2016 & 8 & 1.2 \\
\hline South Korea & 25 & 265 & 2015 & 11 & 0.9 \\
\hline Iran & 25 & 157 & 2016 & 7 & 1.0 \\
\hline Taiwan & 23 & 313 & 2014 & 14 & 1.6 \\
\hline Poland & 18 & 102 & 2016 & 6 & 0.8 \\
\hline Australia & 14 & 126 & 2016 & 9 & 1.5 \\
\hline United Kingdom & 13 & 212 & 2014 & 16 & 2.9 \\
\hline Turkey & 12 & 53 & 2015 & 5 & 0.6 \\
\hline Saudi Arabia & 11 & 103 & 2016 & 10 & 1.0 \\
\hline Hong Kong & 9 & 115 & 2015 & 13 & 1.7 \\
\hline Vietnam & 7 & 173 & 2015 & 25 & 2.5 \\
\hline Egypt & 7 & 58 & 2014 & 9 & 0.8 \\
\hline Greece & 5 & 73 & 2013 & 15 & 0.8 \\
\hline Cyprus & 4 & 47 & 2012 & 12 & 0.8 \\
\hline Lebanon & 4 & 67 & 2016 & 17 & 1.3 \\
\hline
\end{tabular}

Note: Countries/regions in Table 6 are listed based on the number of documents. 


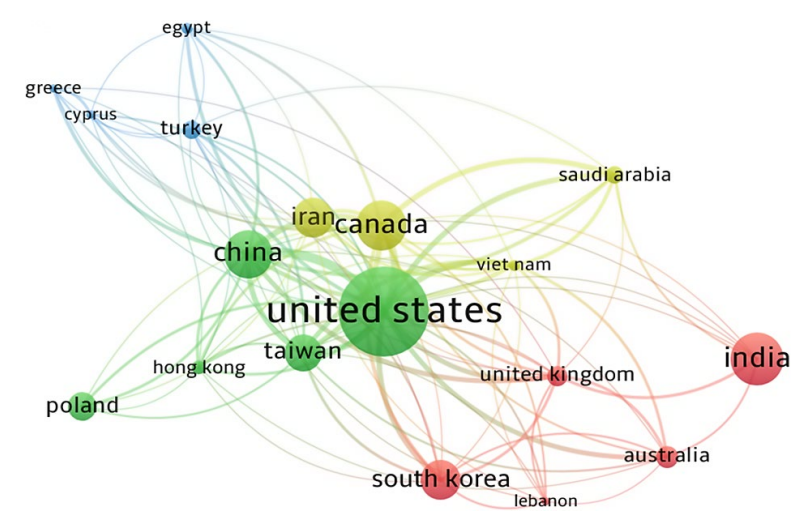

Figure 7. Science mapping of most influential countries/regions

developed and developing countries/regions contributed to the research community in CPS research including United States, Canada, China, Taiwan, Poland and India. Figure 7 and Table 6 shows the summary of quantitative measurement of major countries/regions. In Figure 7, countries/ regions are represented by nodes and connected by lines, which indicates mutual citations of research papers within different countries. It is shown that United States, Canada, India, China and South Korea have larger node size and font size compared to other countries/regions. For example, many research articles regarding optimization of resource constrained schedules have been published in United States (El-Rayes \& Jun, 2009), Taiwan (Hsie et al., 2009), Poland (Jaskowski \& Biruk, 2018; Rosłon \& Kulejewski, 2019), China (Ma \& Xu, 2014), India (Tiwari \& Johari, 2015) and Iran (Kasravi et al., 2019). A summary of quantitative measurements of influential countries/regions in terms of number of articles published, citations received, average citation and normal citations are presented in the Table 6 .

Researchers from United States are ranked first in terms of number of published articles and total citations followed by India, Canada and China. Much research has been done in United States related to resource scheduling such as optimization of time-cost-trade off (Ashuri \& Tavakolan, 2012) and resource requirement fluctuation model (El-Rayes \& Jun, 2009). Developing countries including China and India also conducted research related to time-cost-trade off problems (Zou et al., 2015), ant colony schedule-cost optimization (Li et al., 2013) and resource allocation improvement strategy (Zou et al., 2014). However, countries from Africa have less contribution in CPS research except Egypt which published articles on schedule optimization using swarm particle (Elbeltagi et al., 2016). This result is consistent as most of the construction projects are delayed in African countries. For example, projects in Ethiopia experienced $61-80 \%$ schedule slippage due to schedule management problems (Gebrehiwet \& Luo, 2019). Moreover, developed countries/regions such as United Kingdom, Austria, Taiwan, and United States, and Hong Kong have received a highest average normalized citation indicating that they have noticeable contribution for growth of CPS research.

\section{Qualitative discussion}

Based on scientometric analysis, the authors conducted detailed discussion to provide summary of major research topics, identify research gaps, and propose research framework for future research directions. The detailed discussions are illustrated in the following subsections.

\subsection{Main research topics in CPS}

CPS research covered a wide range of construction and civil engineering project management including project time, cost, quality, risks and human resource management. Based on the type and objectives of study, a variety of research methods and combination of them could be employed such as questionnaire, interview or questionnaire and interview together (Luu et al., 2009), review of existing practices (Al Nasseri et al., 2016), simulation models such as Monte Carlo simulation (Choudhry et al., 2014), mathematical models such as fuzzy sets (Castro-Lacouture et al., 2009) or genetic algorithms for resource scheduling e.g. (Lin \& Hsiau, 2010; Suresh et al., 2011). In this study, the main research topics of CPS during the last decade are categorized as follows.

\subsubsection{Application of scheduling methods}

Analysing the suitability, usability, benefit of CPS methods, and users' experience provides basis for implementation (Al Nasseri et al., 2016). Projects that requires only milestone information may be scheduled using bar chart (Kim, 2012), projects having uncertainty can be scheduled using Program Evaluation Review Technique (PERT) (Hsiau \& Lin, 2009) or combination of CPM with fuzzy set activity representation (Ökmen \& Öztaş, 2014). Other most influential input for the selection of scheduling methods is nature of projects: linear, repetitive or conventional. For instance, linear activities (i.e., activities that are completed as they progress along their path) could be scheduled using Linear Scheduling Method (LSM) (Bonnal et al., 2013) whereas LOB could be used for small number of activities which have repetitive nature (Ali \& Elazouni, 2009; Tomar \& Bansal, 2019). Bonnal et al. (2013) also proposed unified scheduling system by integrating LSM, LOB and precedence diagram method (PDM) for projects having mixture of different kinds of activities. Furthermore, Tomar and Bansal (2019) also developed combination of CPM with LOB for projects having multi-characteristic nature. However, current available scheduling methods could not achieve collaboration of stakeholders due to the nature of multiparty involvement agreement. Yahya and Mohamad (2011) identified lean principles to reduce nonvalue adding activities through team collaboration's planning effort. Similarly, Kovvuri et al. (2016) also found that last planner benefits construction time reduction, quality, cost improvement, build trust, and increase coordination. Moreover, scholars have been continuously developing emerging scheduling methods such as Mahalingam et al. (2015) adopted lean principles with BIM to enhance CPS 
performance via team collaboration. At the same time, CPS risks could be detected and identified to prevent the occurrences of time interruption during execution (Mirzaei et al., 2018).

\subsubsection{Resource constraint scheduling}

Renewable resources could be deployed based on activities' resource consumption so that resources are continuously supplied without constraints. In the real world, construction resources are limited so that they need to be utilized properly. Researchers developed resource optimization systems such as allocation and levelling using mathematical algorithms. For instance, Cheng et al. (2016) developed an application of discrete symbiotic organisms search to manage the fluctuation of temporally hiring and firing of staff and enables cut-off the peak resources requirement. Christodoulou (2010) applied ant colony artificial agent to determine effects of resource constrained using CPM whereas El-Rayes and Jun (2009) focused on resource levelling optimization via genetic algorithm by combining two assumptions: 1) quantifying the required resources during the low resource requirement period and redeploy additional resource for peak period; 2) estimate the wasted days due to fluctuation of resources requirement. Scholars, for example, Zhou et al. (2013) analysed and classified resource constrained CPS into the following categories: (1) mathematical which considers an objective function in the existence of constraints; (2) heuristic to optimize project specific schedule instead of its universality; and (3) metaheuristic for scheduling problems having natural processes such as Pareto optimality genetic algorithm. Genetic algorithm has been widely applied in time-cost trade-off analysis to shorten project duration (Amiri et al., 2017; Tran \& Long, 2018) and time-cost-quality trade-off to enhance quality (Abd El Razek et al., 2010). Al Haj and El-Sayegh (2015) used nonlinear-integer programming to shorten project duration and minimize project cost taking into total float time. Other studies, including but not limited to, Ezeldin and Soliman (2009) developed hybrid method that combined dynamic programming and genetic algorithm to maximize the efficiency of project time and cost under environmental uncertainty.

\subsubsection{Identifying and quantifying schedule risks and uncertainties}

As stated in Luu et al. (2009), material shortages, financial difficulties and lack of experience were identified as the top CPS risks. Scholars identified different CPS risks from different perspectives. For example, financial risk has been identified as the most serious CPS risk both in terms of effect and occurrence (Choudhry et al., 2014; Larsen et al., 2016). A Monte Carlo simulation technique conducted by Liu et al. (2015) indicated that geological risks have high level of risks on tunnel boring machine during design phase. Poor communication between resource planning units, inconsistent information flow in logistics planning system due to human errors probability, precast element delivery delay, and poor information between designer and producer have been identified as CPS risks via Monte Carlo simulation in the production of prefabrication houses in Hong Kong (Shen et al., 2017). Furthermore, Xu et al. (2018) indicated that performing various sensitivity and uncertainty analysis helps for the precise prediction of unknown uncertainties and risks which may cause project delay during an execution of the projects.

\subsubsection{Planning and controlling schedule}

The alignment of planning and scheduling is an essential element of CPS in order to establish basis for controlling and evaluating of project performance. However, factors such as human, technological, organizational and management affect quality of project planning (Tesfaye et al., 2017). Organization's management practices determine how the projects are properly planned within an acceptable schedule practice. Lines et al. (2015) developed precontract model which was implemented between contractor and client prior to the contract award. The model showed that pre-contract planning reduced project cost by $54 \%$ and improved CPS by $70 \%$ with increased client satisfaction. Other studies such as Ryall et al. (2012) identified that LPS brings all stakeholders' effort to develop reliable CPS so that project's track can be effectively controlled. Hamzeh et al. (2012) identified factors affecting last planner system such as existence of non-compliance with LPS rules, and inadequate standardized practices. It has been noticed that CPS planning plays a significant role to develop robust schedule and control compared to planned CPS baseline. Moreover, selection of construction methods during the planning stage is also crucial for successful completion of projects. It does affect the activities, their durations and their work sequences. As a result, a key decision is required for the proper development of construction project in relation to construction methods (Thomas et al., 1990). In this process, scheduling is highly iterative process and demands the project team to examine various data sources and apply own experience to develop a set of efficient methods. Udaipurwala and Russell (2002) examined a case study using actual data via a simulation technique to choose better construction methods. Moreover, lean construction in which all stakeholders involve in the early stage of project with the support of industry practitioners to develop an integrated project schedule (Song et al., 2009).

\subsection{Current research gaps within CPS}

Identifying the forthcoming directions has become an extensive and accepted method to improve the current industry practice (Harty et al., 2007). In this paper, future research directions are identified by synthesizing the most cited previous studies together with the current project schedule requirements. Accordingly, two consecutive steps are used to do this. Firstly, it is necessary to conduct a comprehensive disclosure of the sets of information from previous studies including future directions stated by previous studies to get insights. During the synthesis of 
most cited journal articles, the authors find a "space" to identify future directions. These are regarding gaps that need an improvement or new researches in relation to the current need of scheduling requirement, especially, artificial intelligence (AI) which can help to formulate model and automate tasks (Acemoglu \& Restrepo, 2019). In this step, a number of issues have been listed and categorized including, but not limited to, project early planning, automated schedule performance evaluation, selection of CPS methods, dynamic multi-objective project schedule, project schedule data analytics, and other schedule applications such as BIM and AI-based schedule. Secondly, the authors conducted systematic searching of publications in other databases such as Google scholar and Web of Science using the identified gaps in the first step. Moreover, the most cited journal articles are synthesized using available evidences in conjunction with current scheduling requirements to improve the current industry practice using artificial intelligence techniques. Accordingly, previous studies lack the application of emerging digital technologies in order to improve project schedule performance. May et al. (2018) indicated that construction projects have been significantly affected by loss of productivity, which resulted an average of $20 \%$ schedule slippage due to lack of digitalisation. The application of full digitalization in construction projects can be effectively reduce schedule overruns by $10-15 \%$ (May et al., 2018). For this, the shift towards digital technologies in conjunction with schedule performance management will pave the way for successful implementation of projects. With that in mind, adopting digital technologies to develop construction project schedule is vital to enhance their schedule performance. For instance, BIM has been extensively used in the field of engineering, architecture and construction sectors to build the coordinated and systematic information platform to be accessed by project stakeholders (Succar, 2009). BIM has been still used to reduce project duration through collaboration and communication among stakeholders; and it remains to be favored within the research community in the future (Abdirad \& Pishdad-Bozorgi, 2014; Eleftheriadis et al., 2017). Moreover, Müller and Bostrom (2016) indicated that the development of high-level machine intelligence will be raised by $50 \%$ around $2040-2050$ while rising to $90 \%$ by 2075 in order to increase the consistency and precision of the results. With that in mind, adopting digital technologies and other artificial intelligence in construction projects is vital to enhance schedule performance. Finally, the following current research gaps are categorized for future studies even though wide areas of CPS were addressed in previous studies.

\subsubsection{Front-end schedule reliability assessment}

Front-end planning defined by Faniran et al. (2000) at an early stages of project when crucial and binding elements of project scopes are analysed and incorporated including project's feasibility and execution strategies. This requires an understanding of methods and tools, skills and knowledge, and experience about underlying concepts of planning and scheduling prior to implementation of CPS. AlNasseri and Aulin (2015) indicated that an incorporation of detailed project scope during front-end planning significantly contributes for project success. For instance, Lines et al. (2015) has examined that project duration could be shorten by $54 \%$ and minimized cost by $70 \%$ if pre-contract planning is incorporated. However, front end planning effort is given less attention during the initial project schedule (AlNasseri \& Aulin, 2015; Zwikael, 2009). The study carried by AlNasseri and Aulin (2015) indicated that recognition and adoption of front end planning in construction projects is limited and not sufficiently implemented. The verification of scope of works and identification of project schedule risks were poorly performed in early stage of project (Gannon et al., 2012; Petrochenko et al., 2018). Furthermore, study done by Bragadin and Kähkönen (2016) demonstrated that schedule quality assessment metrics are relevant in order to verify CPS deficiencies in early stages of projects despite the study has limitation in incorporation of CPS risks and perception of stakeholders. For this, the application of artificial intelligence can increase the credibility and precision of the results by automating the tasks (Agarwal et al., 2016). Wang et al. (2012) proposed artificial neural networks to predict project schedule based on projects' early planning information. The study indicated that reliable early planning contributes for an accurate prediction of project success using an automated artificial intelligence models. Thus, identifying the current practice of CPS early planning shortcomings and adequately developing project early planning for complex projects using artificial intelligence techniques such as Support Vector Machines requires further research on front end CPS to develop an integrative schedule review model at the earliest stage of the project.

\subsubsection{Optimizing choice of scheduling methods}

Many researchers investigated applications of different CPS methods. Al Nasseri et al. (2016) indicated that project size and complexity, usability and suitability, underlying basic concepts and theories of these methods, and project manager's capability are some of CPS methods selection parameters. Similar to the identification of the characteristics of each CPS method, projects' parameters and requirements have to be adequately defined to formulate the associated CPS method selection models. For this, manual selection of respective CPS methods for complex projects having a number of project parameters is challenging and time taking, and probably leads to imprecise results. For instance, Rakhshani et al. (2019) adopted deep learning models to provide solutions for enormous nasty optimization problems with an excessive parameters. With that in mind, adopting such kind of artificial intelligence models for selection of CPS methods is vital. Thus, establishing project objectives and other parameters such as duration, cost, risk and quality; and identifying attributes of CPS methods in terms of benefits obtained, time to schedule and technology would be needed further research to provide dynamic CPS methods selection. 


\subsubsection{Optimizing multi-project multi-objective schedule (MPMOS)}

In previous studies, time and cost were well thought-out objectives. Researches have been examining mathematical algorithms to shorten project duration and minimize cost reduction. Ding et al. (2015) and El-Abbasy et al. (2016) developed multi-objective schedule optimization model considering multiple projects having three objectives (i.e., time, cost and quality) based on finish to start activity relationship which lacks priority weight for resource allocation. On the other hand, Elbeltagi et al. (2016) developed schedule optimization model consisting of four objectives (i.e., cost, time, cash flow and resource) for single project. Zhou et al. (2013) conducted literature based study to examine construction schedule optimization using heuristic, mathematical and metaheuristic methods. The study indicated that previous studies have focused on minimization of cost and time, and other factors such as project risk and quality have been neglected. However, organizations could perform multiple projects that are expected to meet a number of objectives such as scope, quality in dynamic environment. Since CPS are affected by various constraints such as productivity, finance, weather, available time and other constraints, further research could focus on developing multi-objective CPS models under considerable project constraints.

\subsubsection{Forecasting schedule risks into activities' duration}

Shen et al. (2017) carried out quantitative schedule risk analysis affecting production of prefabrication housing. The study was conducted to identify and quantitatively evaluate the interactions of major variables in CPS system and the uncertainty of each schedule risk. However, the study has the following two limitations: 1) the model did not consider perspectives of operational project management such as predecessor and successor relationship, and 2) the model established correlation among risk variables instead of duration of activities. Furthermore, Choudhry et al. (2014) identified that CPS risks highly affect project performance are in the absence of schedule mitigation guide lines. With regard to the existing schedule risk analysis methods, some are applicable in deterministic environment where there is no uncertainty; and others have been adopted to analyse the impacts of risks on project duration without any consideration of correlation between risks (Choudhry et al., 2014; Ökmen \& Öztaş, 2008). More recently, there has been a little effort to predict effects of schedule risks by incorporating the correlation between activities' duration and risks. However, all of the method did not consider the correlation between schedule risks (Wang \& Yuan, 2016). For this, a computerized system can be adopted with an assistance of artificial intelligence techniques such as using embedded macros to predict effects of schedule risks (Ökmen \& Öztaş, 2014). Thus, further research could be put in identifying, quantifying and forecasting CPS risks by considering the correlation between schedule risks in addition to the correlation between risks and activities' duration.

\subsubsection{Developing universal schedule efficiency improvement model}

Evaluating the progress of CPS in comparison to baseline schedule enables to make decision on project schedule performance (Hanagodimath et al., 2016). However, many success factors affecting CPS performance such as owners' competence, conflict among stakeholders, poor human resource management, lack of knowledge and ignorance by project manager (Sinesilassie et al., 2017). Within the previous studies, forecasting and evaluating project performance were not addressed very well except few scholars. For example, Baqerin et al. (2016) carried out Weibull analysis to evaluate and forecast CPS performance analysis for repetitive construction projects. Jha and Chockalingam (2011) developed CPS performance prediction model for an ongoing construction project using few significant factors. Thus, developing universal CPS efficiency evaluation model would be promising research on developing dynamic CPS evaluation model to track, measure and forecast CPS performance for the entire project lifecycle including planning, execution, and operation.

\subsubsection{Integrating emerging schedule technologies}

Manual scheduling is time-consuming and prone to error despite it is one of the most integral part of construction projects (Chevallier \& Russell, 1998). As a result, much research has been investigated how schedule generation could be enhanced by automating generation of activity, estimation of duration and determining sequence logic with the support of emerging technologies. For this, BIM is increasingly an important for scheduling since it provides a significant support for this complex task by reducing planning time and increase productivity (Sigalov \& König, 2017). Sigalov and König (2017) developed automatic detection of construction processes patterns with an emphasis on preparation of schedules for the recognition of process patterns, including breakdown of schedules into smaller parts. Moreover, various types of spaces can be represented within $4 \mathrm{D}$ CAD simulation model that are required by activities in the site across their scheduled time. This enables to describe space, time and time period they exist including the volume they occupy in order to detect time-space conflict, and proactive planning prior to construction (Akinci et al., 2002). Mirzaei et al. (2018) indicated that the demonstration of labour crew movement simulation in three dimensional design geometry provides an insight for development of 4D-BIM time-space clash detection. Using the design data property such as spatial data, material layer and relationship, generation of CPS creates activities, estimate activity duration, determine sequences, and finally produce a schedule (Anderson et al., 2013). Moreover, Wang and Rezazadeh Azar (2019) developed an automated 4D-BIM CPS and Chen et al. (2011) combined BIM with genetic algorithm to assign crews for general contractor's schedule mainly for construction of building frames (i.e., wall, column, beam and slab). Vignesh (2017) has examined contractor's work flow using 
LPS. Practically, there are number of trades of works that are sub-contracted for various project stakeholders such as electrical, mechanical, plumbing, heat, ventilation and other advanced building facilities to be included in BIM based CPS. Since web-based CPS are affected by various constraints such as productivity, finance, weather, available time and other constraints, further research could put in 4D-BIM and last planner to develop an integrated CPS in early stage of works and removal of constraints.

\subsubsection{Application of big data analytics for examining construction schedule performance}

Construction industry has been employing many scheduling tools and methods to improve construction work flows. For instance, BIM has been serving as one of the most innovative revitalization technology in the construction project schedule (Hardin \& McCool, 2015). BIM data (i.e., intensive and multi-dimensional building information) is typically kept in $3 \mathrm{D}$ geometrical design (i.e., BIM) software products based on their specific file formats even though they use Industry Foundation Classes (IFC) as a common BIM file format. All specific file formats are opened through project management mode of particular BIM software product. Accordingly, all their files must be opened through a particular BIM software in order to visualize the three-dimensional model and various disciples' design property, which helps to support collabora- tion among project stakeholders (Chang \& Chen, 2015; Han \& Golparvar-Fard, 2017). With an increasing recent advances in sensors and smart devices, projects thus have started generating large volume of data during the entire project life, which eventually leading to large volume of BIM data (Han \& Golparvar-Fard, 2017). Due to this vast build-up of data, construction industry has recently grown beyond 'BIM' such as big data analytics. Bilal et al. (2016) characterized big data using three attributes: large volume of data, variety of file formats and continuous flow of data. Construction data is a diverse and voluminous due to number of BIM data, including large volume of design data and project schedule. Researchers have been dedicating to combine big data with streaming nature of construction data sources such as building information management, and creating an integrated schedule management system using GIS or BIM through the application of sensors. Thus, with the support of automatic data collection method, researchers can apply big data analytics technology to examine off-site and on-site schedule management performance.

\subsection{Research trends within CPS}

Based on the discussion of major research topics and gaps, the framework of future potential CPS research directions are proposed as shown in Figure 8.

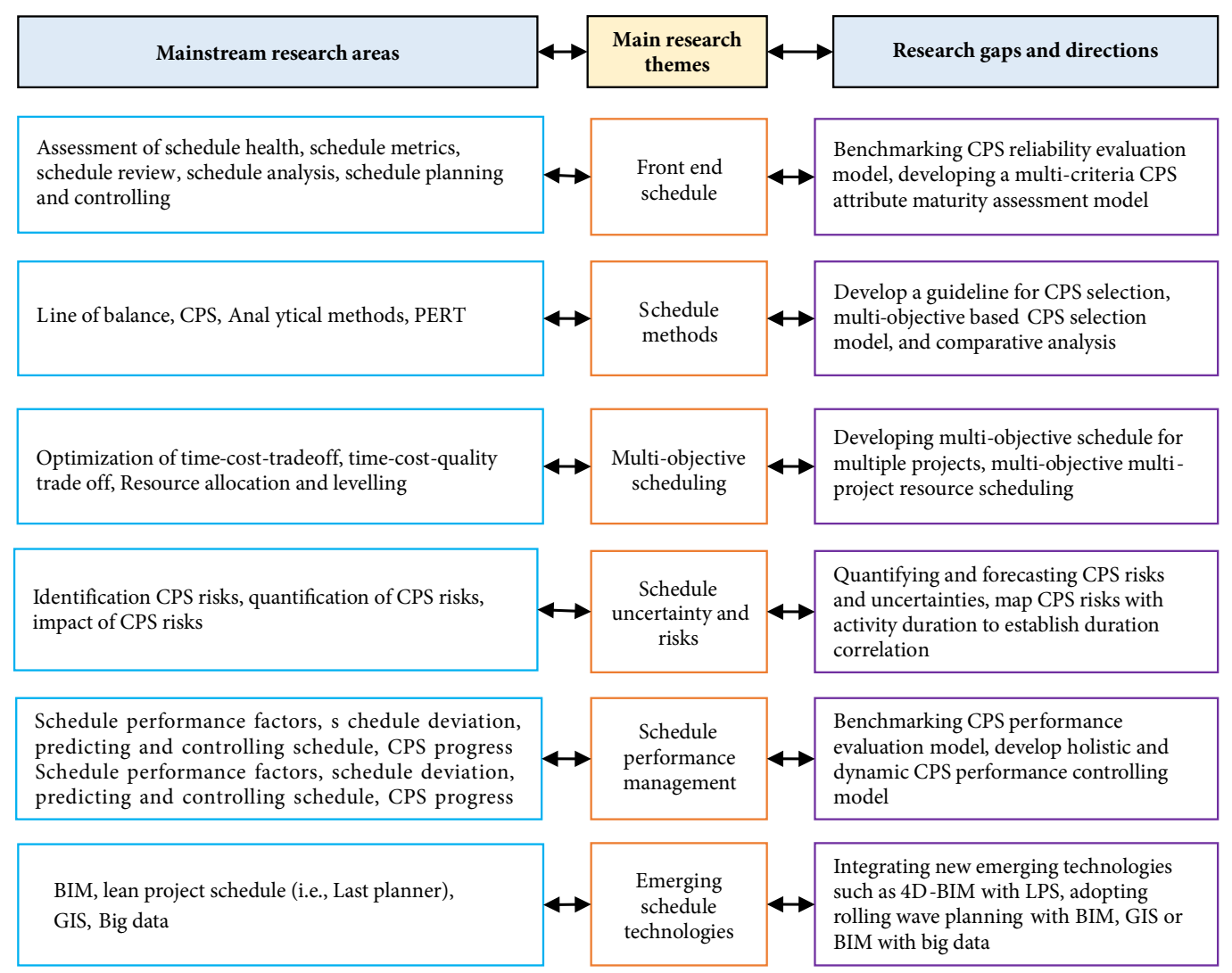

Figure 8. Comprehensive proposed frame work for CPS: Research areas and directions 
More promising future research directions can be summarized below:

- A comprehensive benchmarking of CPS assessment in early stage of CPS development is to validate the constructability of CPS including incorporation of required scopes represented by activity, verify that CPS risks are adequately modelled, and check logical formulation of schedule metrics;

- Forecasting robust CPS still needs research in development of front-end CPS reliability model together with multidimensional aspects of project such as scope, risks, schedule metrics and reasonable estimation of duration prior to the start of construction to detect the deficiency of CPS;

- Investigating on taxonomy of CPS methods by $\mathrm{Al}$ Nasseri et al. (2016) has been conducted. It has been identified that further research is required in developing an optimized CPS method selection model using identified parameters usability, extent of adoptability, limitations and coverage of each methods in relation to project scope such as size and complexity;

- Studies in achieving multiple objectives for multiple projects at the same time could drive motivation for further research. For example, multi-objective schedule optimization model for multiple projects (El-Abbasy et al., 2016), multi-objective schedule optimization for single project (Elbeltagi et al., 2016). It is anticipated that these previous studies information plus the application of modern optimization algorithms would be more developed in future research of CPS for multiple projects' objective within unknown project uncertainties;

- A more comprehensive quantification system of CPS risks needs to be developed to accurately predict the probable effects of CPS risks. Even though, identifying an extent of impacts of schedule risks provides the probable effects of schedule risks on overall project duration, mapping CPS risks into activity duration is more binding to identify most sensitive activities. Thus, forecasting CPS risks based on impacted activity duration could put future research in the domain of CPS using proposed framework as shown in the Figure 8, and quantification of CPS risks initiated by Liu et al. (2015);

- An advanced CPS planning and management system can be incorporated for the entire life cycle of project starting in the early stage of project planning and design stage. Developing 4D-BIM-Last Planner system using an integration of 3D-design geometry and rolling wave planning principle would be implemented in order to reduce CPS risks and uncertainties;

- Examining off-site and on-site schedule management performance using Big data analytics technology with the support of automatic construction data collection systems such as sensors and smart devices.

\section{Conclusions}

In this paper, holistic literature review-based study was implemented in the domain of construction project schedule. A bibliometric literature retrieval and scientometric analysis were used with detailed qualitative explanation. A total of 332 journal articles were chosen since 2009 . The scientometric analysis illustrates the most prominent journals, keywords, co-author analysis, articles, and countries/ regions in the research of CPS.

Based on scientometric analysis followed by detailed qualitative discussion, main research topics and research gaps in the domain of CPS are identified; and simultaneously future research directions are proposed. The major research topics include mathematical algorithms-based resource scheduling optimizations, CPS methods and applications, identification and quantification of CPS risks, and CPS planning and controlling. The gaps of existing research studies include front-end CPS constructability assessment, optimizing CPS methods selection, multi-objective for multiple project schedule optimization, mapping and forecasting of CPS risks into activity duration, CPS performance evaluation, and integrating emerging schedule technologies. The study also proposes future research directions.

This review-based study in CPS was limited to bibliometric literature samples. The study only focused journal articles written in the English language in the domain of CPS academic research areas in Scopus database source. Other sources, including conferences were excluded. Thus, there would be further research to discover the uncertainty between the latest industry practices and the scholarly research.

\section{Acknowledgements}

The authors acknowledge the unnamed referees for their useful suggestions.

\section{Funding}

This study was partly supported by the National Natural Science Foundation of China (NSFC) under grant no. 71502008; and supported by the Fundamental Research Funds for the Central Universities in China; and supported by the Social Science Funds of Beijing under grant no. 16GLC047 and 71843011.

\section{Author contributions}

Mr. Derbe was responsible for data collection from Scopus database, results analysis, interpretation, discussion and conclusion. Dr. Li conducted the detailed construction project schedule (CPS) analysis and wrote the first draft of the article. Dr. Wu checked the related arcticles from Google Scholar, Scopus and Web of Science and provided the corresponding analysis. Dr. Zhao proposed the review method scheme and refined the submission to Journal of Civil Engineering and Management. 


\section{Disclosure statement}

We affirm that we have no any financial, personal, or professional interests from other parties.

\section{References}

Abbondati, F., Lamberti, R., \& Capaldo, F. S. (2016). Linear scheduling analysis toolkit for road and airports construction projects. ARPN Journal of Engineering and Applied Sciences, 11(11), 6863-6874.

Abd El Razek, R. H., Diab, A. M., Hafez, S. M., \& Aziz, R. F. (2010). Time-cost-quality trade-off software by using simplified Genetic algorithm for typical-repetitive construction projects. World Academy of Science, Engineering and Technology, $61,312-321$.

Abdirad, H., \& Pishdad-Bozorgi, P. (2014). Trends of assessing BIM implementation in construction research. In 2014 International Conference on Computing in Civil and Building Engineering (pp. 496-503). Orlando, Florida, United States. https://doi.org/10.1061/9780784413616.062

Abou-Ibrahim, H., Hamzeh, F., Zankoul, E., Munch Lindhard, S., \& Rizk, L. (2019). Understanding the planner's role in lookahead construction planning. Production Planning and Control, 30(4), 271-284.

https://doi.org/10.1080/09537287.2018.1524163

Acemoglu, D., \& Restrepo, P. (2019). The wrong kind of AI? Artificial intelligence and the future of labor demand. Cambridge Journal of Regions, Economy and Society.

https://doi.org/10.1093/cjres/rsz022

Agarwal, R., Chandrasekaran, S., \& Sridhar, M. (2016). Imagining construction's digital future. McKinsey Productivity Sciences Center. https://www.mckinsey.com/industries/capitalprojects-and-infrastructure/our-insights/imagining-constructions-digital-future

Aghaei Chadegani, A., Salehi, H., Yunus, M., Farhadi, H., Fooladi, M., Farhadi, M., \& Ale Ebrahim, N. (2013). A comparison between two main academic literature collections: Web of Science and Scopus databases. Asian Social Science, 9(5), 18-26. https://doi.org/10.5539/ass.v9n5p18

Akinci, B., Fischer, M., \& Kunz, J. (2002). Automated generation of work spaces required by construction activities. Journal of Construction Engineering and Management, 128(4), 306-315. https://doi.org/10.1061/(ASCE)0733-9364(2002)128:4(306)

Al Haj, R. A., \& El-Sayegh, S. M. (2015). Time-cost optimization model considering float-consumption impact. Journal of Construction Engineering and Management, 141(5), 04015001. https://doi.org/10.1061/(ASCE)CO.1943-7862.0000966

Al Nasseri, H., \& Aulin, R. (2016). Enablers and barriers to project planning and scheduling based on construction projects in Oman. Journal of Construction in Developing Countries, 21(2), 1-20. https://doi.org/10.21315/jcdc2016.21.2.1

Al Nasseri, H., Widen, K., \& Aulin, R. (2016). A taxonomy of planning and scheduling methods to support their more efficient use in construction project management. Journal of Engineering, Design and Technology, 14(3), 580-601.

https://doi.org/10.1108/JEDT-11-2013-0078

Ali, M. M., \& Elazouni, A. (2009). Finance-based CPM/LOB scheduling of projects with repetitive non-serial activities. Construction Management and Economics, 27(9), 839-856. https://doi.org/10.1080/01446190903191764

Alias, S. E., \& Ismail, N. (2012). The usage of critical path method software in Malaysian construction. International Journal of Knowledge, Culture and Change Management, 11(5), 77-88. https://doi.org/10.18848/1447-9524/CGP/v11i05/50198
Aliverdi, R., Moslemi Naeni, L., \& Salehipour, A. (2013). Monitoring project duration and cost in a construction project by applying statistical quality control charts. International Journal of Project Management, 31(3), 411-423.

https://doi.org/10.1016/j.ijproman.2012.08.005

AlNasseri, H., \& Aulin, R. (2015). Assessing understanding of planning and scheduling theory and practice on construction projects. EMJ - Engineering Management Journal, 27(2), 58-72. https://doi.org/10.1080/10429247.2015.1035963

Alsehaimi, A. O., Fazenda, P. T., \& Koskela, L. (2014). Improving construction management practice with the Last Planner System: A case study. Engineering, Construction and Architectural Management, 21(1), 51-64. https://doi.org/10.1108/ECAM-03-2012-0032

Amiri, M. J. T., Haghighi, F., Eshtehardian, E., Hematian, M., \& Kordi, H. (2017). Optimization of time and cost in critical chain project scheduling problem using genetic algorithm. Journal of Engineering and Applied Sciences, 12(4), 871-876.

Anderson, K., Kim, H., Lee, S., \& Hildreth, J. (2013). Generating construction schedules through automatic data extraction using open BIM (building information modeling) technology. Automation in Construction, 35, 285-295.

https://doi.org/10.1016/j.autcon.2013.05.020

Ashuri, B., \& Tavakolan, M. (2012). Fuzzy enabled hybrid genetic algorithm-particle swarm optimization approach to solve TCRO problems in construction project planning. Journal of Construction Engineering and Management, 138(9), 10651074. https://doi.org/10.1061/(ASCE)CO.1943-7862.0000513

Bakkalbasi, N., Bauer, K., Glover, J., \& Wang, L. (2006). Three options for citation tracking: Google Scholar, Scopus and Web of Science. Biomedical Digital Libraries, 3(1), 7. https://doi.org/10.1186/1742-5581-3-7

Bakry, I., Moselhi, O., \& Zayed, T. (2016). Optimized scheduling and buffering of repetitive construction projects under uncertainty. Engineering, Construction and Architectural Management, 23(6), 782-800. https://doi.org/10.1108/ECAM-05-2014-0069

Ballesteros-Pérez, P., Elamrousy, K. M., \& González-Cruz, M. C. (2019). Non-linear time-cost trade-off models of activity crashing: Application to construction scheduling and project compression with fast-tracking. Automation in Construction, 97, 229-240. https://doi.org/10.1016/j.autcon.2018.11.001

Băncescu, M. (2016). Controlling project schedule progress, using control charts. Cybernetics and Systems, 47(7), 602-615. https://doi.org/10.1080/01969722.2016.1211883

Bankar, R. S., \& Lihitkar, S. R. (2019). Science mapping and visualization tools used for bibliometric and scientometric studies: A comparative study. Journal of Advancements in Library Sciences, 6(1), 382-394.

Bansal, V. K., \& Pal, M. (2009). Construction schedule review in GIS with a navigable 3D animation of project activities. International Journal of Project Management, 27(5), 532-542. https://doi.org/10.1016/j.ijproman.2008.07.004

Baqerin, M. H., Shafahi, Y., \& Kashani, H. (2016). Application of Weibull analysis to evaluate and forecast schedule performance in repetitive projects. Journal of Construction Engineering and Management, 142(2), 04015058.

https://doi.org/10.1061/(ASCE)CO.1943-7862.0001040

Bilal, M., Oyedele, L. O., Qadir, J., Munir, K., Ajayi, S. O., Akinade, O. O., Owolabi, H. A., Alaka, H. A., \& Pasha, M. (2016). Big Data in the construction industry: A review of present status, opportunities, and future trends. Advanced Engineering Informatics, 30(3), 500-521.

https://doi.org/10.1016/j.aei.2016.07.001 
Bonnal, P., Baudin, M., \& De Jonghe, J. (2013). Merging PDM, RSM and LSM scheduling approaches: Into a single construction project scheduling system. Journal of Modern Project Management, 1(2), 6-17.

Bragadin, M. A., \& Kähkönen, K. (2016). Schedule health assessment of construction projects. Construction Management and Economics, 34(12), 875-897.

https://doi.org/10.1080/01446193.2016.1205751

Castro-Lacouture, D., Süer, G. A., Gonzalez-Joaqui, J., \& Yates, J. K. (2009). Construction project scheduling with time, cost, and material restrictions using fuzzy mathematical models and critical path method. Journal of Construction Engineering and Management, 135(10), 1096-1104.

https://doi.org/10.1061/(ASCE)0733-9364(2009)135:10(1096)

Chan, G., Li, H., Skitmore, M., \& Huang, T. (2015). A 4D automatic simulation tool for construction resource planning: A case study. Engineering, Construction and Architectural Management, 22(5), 536-550.

https://doi.org/10.1108/ECAM-07-2014-0093

Chang, K., \& Chen, H. (2015). A cloud-based system framework for storage and analysis on Big Data of massive BIMs. In Proceedings of the International Symposium on Automation and Robotics in Construction (ISARC 2015). Oulu, Finland. https://doi.org/10.22260/ISARC2015/0001

Chen, Y., Feng, C., Wang, Y., \& Wu, H. (2011). Using bim model and genetic algorithms to optimize the crew assignment for construction project planning. International Journal of Technology, 2(3), 179-188.

Cheng, M. Y., Prayogo, D., \& Tran, D. H. (2016). Optimizing multiple-resources leveling in multiple projects using discrete symbiotic organisms search. Journal of Computing in Civil Engineering, 30(3), 04015036.

https://doi.org/10.1061/(ASCE)CP.1943-5487.0000512

Chevallier, N., \& Russell, A. D. (1998). Automated schedule generation. Canadian Journal of Civil Engineering, 25(6), 10591077. https://doi.org/10.1139/198-029

Choudhry, R. M., Aslam, M. A., \& Arain, F. M. (2014). Cost and schedule risk analysis of bridge construction in Pakistan: Establishing risk guidelines. Journal of Construction Engineering and Management, 140(7), 04014020.

https://doi.org/10.1061/(ASCE)CO.1943-7862.0000857

Christodoulou, S. E. (2010). Scheduling resource-constrained projects with ant colony optimization artificial agents. Journal of Computing in Civil Engineering, 24(1), 45-55.

https://doi.org/10.1061/(ASCE)0887-3801(2010)24:1(45)

Christodoulou, S. E., Tezias, E. S., \& Galaras, K. A. (2012). Resource-constrained scheduling of construction projects and simulation of the entropy impact on a project's duration and cost. International Journal of Project Organisation and Management, 4(4), 322-338. https://doi.org/10.1504/IJPOM.2012.050328

Cobo, M. J., López-Herrera, A. G., Herrera-Viedma, E., \& Herrera, F. (2011). Science mapping software tools: Review, analysis, and cooperative study among tools. Journal of the American Society for Information Science and Technology, 62(7), 1382-1402. https://doi.org/10.1002/asi.21525

Daniel, E. I., Pasquire, C., Dickens, G., \& Ballard, H. G. (2017). The relationship between the last planner\&reg; System and collaborative planning practice in UK construction. Engineering, Construction and Architectural Management, 24(3), 407-425. https://doi.org/10.1108/ECAM-07-2015-0109

Ding, L., Zhou, Y., Wang, X., Truijens, M., \& Luo, H. (2015). Applicability of 4D modeling for resource allocation in mega liquefied natural gas plant construction. Automation in Construction, 50(C), 50-63.

https://doi.org/10.1016/j.autcon.2014.10.016
Dochy, F. (2006). A guide for writing scholarly articles or reviews for the Educational Research Review. Educational Research Review, 4.

El-Abbasy, M. S., Elazouni, A., \& Zayed, T. (2016). MOSCOPEA: Multi-objective construction scheduling optimization using elitist non-dominated sorting genetic algorithm. Automation in Construction, 71(Part 2), 153-170.

https://doi.org/10.1016/j.autcon.2016.08.038

El-Rayes, K., \& Jun, D. H. (2009). Optimizing resource leveling in construction projects. Journal of Construction Engineering and Management, 135(11), 1172-1180. https://doi.org/10.1061/(ASCE)CO.1943-7862.0000097

Elbeltagi, E., Ammar, M., Sanad, H., \& Kassab, M. (2016). Overall multiobjective optimization of construction projects scheduling using particle swarm. Engineering, Construction and Architectural Management, 23(3), 265-282.

https://doi.org/10.1108/ECAM-11-2014-0135

Eleftheriadis, S., Mumovic, D., \& Greening, P. (2017). Life cycle energy efficiency in building structures: A review of current developments and future outlooks based on BIM capabilities. Renewable and Sustainable Energy Reviews, 67, 811-825. https://doi.org/10.1016/j.rser.2016.09.028

Eshtehardian, E., Afshar, A., \& Abbasnia, R. (2009). Fuzzy-based MOGA approach to stochastic time-cost trade-off problem. Automation in Construction, 18(5), 692-701.

https://doi.org/10.1016/j.autcon.2009.02.001

Ezeldin, A. S., \& Soliman, A. (2009). Hybrid time-cost optimization of nonserial repetitive construction projects. Journal of Construction Engineering and Management, 135(1), 42-55. https://doi.org/10.1061/(ASCE)0733-9364(2009)135:1(42)

Faghihi, V., Nejat, A., Reinschmidt, K. F., \& Kang, J. H. (2015). Automation in construction scheduling: a review of the literature. International Journal of Advanced Manufacturing Technology, 81(9-12), 1845-1856.

https://doi.org/10.1007/s00170-015-7339-0

Faghihi, V., Reinschmidt, K. F., \& Kang, J. H. (2014). Construction scheduling using Genetic Algorithm based on Building Information Model. Expert Systems with Applications, 41(16), 7565-7578. https://doi.org/10.1016/j.eswa.2014.05.047

Falagas, M. E., Pitsouni, E. I., Malietzis, G. A., \& Pappas, G. (2008). Comparison of PubMed, Scopus, Web of Science, and Google scholar: strengths and weaknesses. The FASEB Journal, 22(2), 338-342. https://doi.org/10.1096/fj.07-9492LSF

Faniran, O., Love, P., \& Smith, J. (2000). Effective front-end project management - a key element in achieving project success in developing countries. In Proceedings of Construction Development Conference.

Gannon, T., Feng, P., \& Sitzabee, W. (2012). Reliable schedule forecasting in federal design-build facility procurement. Lean Construction Journal, 1-14.

García-Nieves, J. D., Ponz-Tienda, J. L., Salcedo-Bernal, A., \& Pellicer, E. (2018). The multimode resource-constrained project scheduling problem for repetitive activities in construction projects. Computer-Aided Civil and Infrastructure Engineering, 33(8), 655-671. https://doi.org/10.1111/mice.12356

Gebrehiwet, T., \& Luo, H. (2019). Risk level evaluation on construction project lifecycle using fuzzy comprehensive evaluation and TOPSIS. Symmetry, 11(1), 12. https://doi.org/10.3390/sym11010012

Ghoddousi, P., Ansari, R., \& Makui, A. (2017). An improved robust buffer allocation method for the project scheduling problem. Engineering Optimization, 49(4), 718-731. https://doi.org/10.1080/0305215X.2016.1206534 
Giran, O., Temur, R., \& Bekdaş, G. (2017). Resource constrained project scheduling by harmony search algorithm. KSCE Journal of Civil Engineering, 21(2), 479-487.

https://doi.org/10.1007/s12205-017-1363-6

González, V., Alarcón, L. F., \& Molenaar, K. (2009). Multiobjective design of Work-In-Process buffer for scheduling repetitive building projects. Automation in Construction, 18(2), 95-108. https://doi.org/10.1016/j.autcon.2008.05.005

Gwak, H. S., Son, S. H., Park, Y. J., \& Lee, D. E. (2016). Exact time-cost tradeoff analysis in concurrency-based scheduling. Journal of Construction Engineering and Management, 142(10), 04016054.

https://doi.org/10.1061/(ASCE)CO.1943-7862.0001164

Hamzeh, F., Ballard, G., \& Tommelein, I. D. (2012). Rethinking lookahead planning to optimize construction workflow. Lean Construction Journal, 15-34.

Han, K. K., \& Golparvar-Fard, M. (2017). Potential of big visual data and building information modeling for construction performance analytics: An exploratory study. Automation in Construction, 73, 184-198.

https://doi.org/10.1016/j.autcon.2016.11.004

Hanagodimath, A. V., Rajashekarswamy, H. M., \& Parate, H. R. (2016). Project performance in real time construction industry - A case study. International Journal of Civil Engineering and Technology, 7(5), 93-102.

Hardin, B., \& McCool, D. (2015). BIM and construction management: proven tools, methods, and workflows. John Wiley $\&$ Sons.

Harty, C., Goodier, C. I., Soetanto, R., Austin, S., Dainty, A. R., \& Price, A. D. (2007). The futures of construction: a critical review of construction future studies. Construction Management and Economics, 25(5), 477-493.

https://doi.org/10.1080/01446190600879117

He, Q., Wang, G., Luo, L., Shi, Q., Xie, J., \& Meng, X. (2017). Mapping the managerial areas of Building Information Modeling (BIM) using scientometric analysis. International Journal of Project Management, 35(4), 670-685. https://doi. org/10.1016/j.ijproman.2016.08.001

Hosseini, M. R., Martek, I., Zavadskas, E. K., Aibinu, A. A., Arashpour, M., \& Chileshe, N. (2018). Critical evaluation of offsite construction research: A Scientometric analysis. Automation in Construction, 87, 235-247.

https://doi.org/10.1016/j.autcon.2017.12.002

Hsiau, H. J., \& Lin, C. W. R. (2009). A fuzzy pert approach to evaluate plant construction project scheduling risk under uncertain resources capacity. Journal of Industrial Engineering and Management, 2(1), 31-47.

https://doi.org/10.3926/jiem.2009.v2n1.p31-47

Hsie, M., Chang, C. J., Yang, I. T., \& Huang, C. Y. (2009). Resource-constrained scheduling for continuous repetitive projects with time-based production units. Automation in Construction, 18(7), 942-949.

https://doi.org/10.1016/j.autcon.2009.04.006

Huang, K. M., Yang, B., Lee, C. H., \& Chiu, C. T. (2014). Incorporating lost productivity calculation into delay analysis for construction projects. KSCE Journal of Civil Engineering, 18(2), 380-388. https://doi.org/10.1007/s12205-014-0128-8

Indhu, B., \& Farhan, M. (2015). Analysis of probabilistic times in a construction project using Monte Carlo simulation technique. International Journal of Applied Engineering Research, 10(10), 26463-26474.

Jacsó, P. (2005). Google Scholar: the pros and the cons. Online Information Review, 29(2), 208-214.

https://doi.org/10.1108/14684520510598066
Jaskowski, P., \& Biruk, S. (2018). Reducing renewable resource demand fluctuation using soft precedence relations in project scheduling. Journal of Civil Engineering and Management, 24(4), 355-363. https://doi.org/10.3846/jcem.2018.3043

Jha, K. N., \& Chockalingam, C. T. (2011). Prediction of schedule performance of Indian construction projects using an artificial neural network. Construction Management and Economics, 29(9), 901-911. https://doi.org/10.1080/01446193.2011.608691

Jin, R., Yuan, H., \& Chen, Q. (2019a). Science mapping approach to assisting the review of construction and demolition waste management research published between 2009 and 2018. Resources, Conservation and Recycling, 140, 175-188. https://doi.org/10.1016/j.resconrec.2018.09.029

Jin, R., Zou, P. X., Piroozfar, P., Wood, H., Yang, Y., Yan, L., \& Han, Y. (2019b). A science mapping approach based review of construction safety research. Safety Science, 113, 285-297. https://doi.org/10.1016/j.ssci.2018.12.006

Kasravi, M., Mahmoudi, A., \& Feylizadeh, M. R. (2019). A novel algorithm for solving resource-constrained project scheduling problems: a case study. Journal of Advances in Management Research, 16(2), 194-215.

https://doi.org/10.1108/JAMR-03-2018-0033

Kastor, A., \& Sirakoulis, K. (2009). The effectiveness of resource levelling tools for resource constraint project scheduling problem. International Journal of Project Management, 27(5), 493-500. https://doi.org/10.1016/j.ijproman.2008.08.006

Kavuma, A., Ock, J., \& Jang, H. (2019). Factors influencing time and cost overruns on freeform construction projects. KSCE Journal of Civil Engineering, 23(4), 1442-1450. https://doi.org/10.1007/s12205-019-0447-x

Khanzadi, M., Movahedian, A., \& Bagherpour, M. (2016). Finding optimum resource allocation to optimizing construction project Time/Cost through combination of artificial agents CPM and GA. Periodica Polytechnica Civil Engineering, 60(2), 169-180. https://doi.org/10.3311/PPci.7883

Kim, S. G. (2012). CPM schedule summarizing function of the beeline diagramming method. Journal of Asian Architecture and Building Engineering, 11(2), 367-374.

https://doi.org/10.3130/jaabe.11.367

Kovvuri, P. R. R., Sawhney, A., Ahuja, R., \& Sreekumar, A. (2016). Efficient project delivery using lean principles - An Indian case study. Journal of The Institution of Engineers (India): Series A, 97(1), 19-26.

https://doi.org/10.1007/s40030-016-0142-6

Larsen, J. K., Shen, G. Q., Lindhard, S. M., \& Brunoe, T. D. (2016). Factors affecting schedule delay, cost overrun, and quality level in public construction projects. Journal of Management in Engineering, 32(1), 04015032.

https://doi.org/10.1061/(ASCE)ME.1943-5479.0000391

Larsen, J. K., Lindhard, S. M., Brunoe, T. D., \& Jensen, K. N. (2018). The relation between pre-planning, commissioning and enhanced project performance. Construction Economics and Building, 18(2), 1-14.

https://doi.org/10.5130/AJCEB.v18i2.5762

Lekshmi, S. A., \& Unnikrishnan, V. (2018). Planning and delay analysis of a residential complex: A case study. International Journal of Civil Engineering and Technology, 9(6), 1191-1201.

Li, H., \& Zhang, H. (2013). Ant colony optimization-based multi-mode scheduling under renewable and nonrenewable resource constraints. Automation in Construction, 35, 431-438. https://doi.org/10.1016/j.autcon.2013.05.030

Li, H., Zhang, J., Ren, L., \& Shi, Z. (2013). Scheduling optimization in construction project based on ant colony genetic algorithm. Journal of Theoretical and Applied Information Technology, 48(3), 1540-1545. 
Lin, C. W. R., \& Hsiau, H. J. (2010). A genetic algorithm approach for optimizing chemical towers construction project scheduling with dynamic resources constraints. International Journal of Industrial Engineering: Theory Applications and Practice, 17(2), 128-141.

Lines, B. C., Sullivan, K. T., Hurtado, K. C., \& Savicky, J. (2015). Planning in construction: Longitudinal study of pre-contract planning model demonstrates reduction in project cost and schedule growth. International Journal of Construction Education and Research, 11(1), 21-39.

https://doi.org/10.1080/15578771.2013.872733

Liu, D., Xuan, P., Li, S., \& Huang, P. (2015). Schedule risk analysis for TBM tunneling based on adaptive CYCLONE simulation in a geologic uncertainty-aware context. Journal of Computing in Civil Engineering, 29(6), 04014103.

https://doi.org/10.1061/(ASCE)CP.1943-5487.0000441

Long, L. D., \& Ohsato, A. (2009). A genetic algorithm-based method for scheduling repetitive construction projects. $\mathrm{Au}$ tomation in Construction, 18(4), 499-511.

https://doi.org/10.1016/j.autcon.2008.11.005

Luu, V. T., Kim, S. Y., Tuan, N. V., \& Ogunlana, S. O. (2009). Quantifying schedule risk in construction projects using Bayesian belief networks. International Journal of Project Management, 27(1), 39-50.

https://doi.org/10.1016/j.ijproman.2008.03.003

Ma, Y., \& Xu, J. (2014). A novel multiple decision-maker model for resource-constrained project scheduling problems. Canadian Journal of Civil Engineering, 41(6), 500-511. https://doi.org/10.1139/cjce-2013-0232

Mahalingam, A., Yadav, A. K., \& Varaprasad, J. (2015). Investigating the role of lean practices in enabling BIM adoption: Evidence from two Indian cases. Journal of Construction Engineering and Management, 141(7), 05015006.

https://doi.org/10.1061/(ASCE)CO.1943-7862.0000982

Martín-Martín, A., Orduna-Malea, E., Thelwall, M., \& LópezCózar, E. D. (2018). Google Scholar, Web of Science, and Scopus: A systematic comparison of citations in 252 subject categories. Journal of Informetrics, 12(4), 1160-1177. https://doi.org/10.1016/j.joi.2018.09.002

May, I., Pynn, C., \& Hill, P. (2018). Arup's digital future: The path to BIM. In Building Information Modeling (pp. 509-534). Springer. https://doi.org/10.1007/978-3-319-92862-3_31

McCabe, B., AbouRizk, S. M., \& Goebel, R. (1998). Belief networks for construction performance diagnostics. Journal of Computing in Civil Engineering, 12(2), 93-100.

https://doi.org/10.1061/(ASCE)0887-3801(1998)12:2(93)

Meho, L. I., \& Yang, K. (2006). A new era in citation and bibliometric analyses: Web of Science, Scopus, and Google Scholar. Journal of the American Society for Information Science and Technology (accepted for publication).

Mirzaei, A., Nasirzadeh, F., Parchami Jalal, M., \& Zamani, Y. (2018). 4D-BIM dynamic time-space conflict detection and quantification system for building construction projects. Journal of Construction Engineering and Management, 144(7), 04018056.

https://doi.org/10.1061/(ASCE)CO.1943-7862.0001504

Moselhi, O., \& Alshibani, A. (2013). Schedule compression using Fuzzy Set Theory and contractors judgment. Journal of Information Technology in Construction, 18, 64-75.

Müller, V. C., \& Bostrom, N. (2016). Future progress in artificial intelligence: A survey of expert opinion. In Fundamental Issues of Artificial Intelligence (pp. 555-572). Springer. https://doi.org/10.1007/978-3-319-26485-1_33

Ökmen, Ö., \& Öztaş, A. (2008). Construction project network evaluation with correlated schedule risk analysis model. Jour- nal of Construction Engineering and Management, 134(1), 4963. https://doi.org/10.1061/(ASCE)0733-9364(2008)134:1(49)

Ökmen, Ö., \& Öztaş, A. (2014). A CPM-based scheduling method for construction projects with fuzzy sets and fuzzy operations. Journal of the South African Institution of Civil Engineering, 56(2), 2-8.

Petrochenko, M. V., Velichkin, V. Z., Kazakov, Y. N., \& Zavodnova, Y. B. (2018). Reliability assessment of the construction schedule by the critical chain method. Magazine of Civil Engineering, 81(5), 25-31.

Poshdar, M., González, V. A., Raftery, G. M., Orozco, F., \& Cabrera-Guerrero, G. G. (2018). A multi-objective probabilistic-based method to determine optimum allocation of time buffer in construction schedules. Automation in Construction, 92, 46-58. https://doi.org/10.1016/j.autcon.2018.03.025

Poshdar, M., González, V. A., Raftery, G. M., Orozco, F., Romeo, J. S., \& Forcael, E. (2016). A probabilistic-based method to determine optimum size of project buffer in construction schedules. Journal of Construction Engineering and Management, 142(10), 04016046.

https://doi.org/10.1061/(ASCE)CO.1943-7862.0001158

Radziszewska-Zielina, E., Śladowski, G., \& Sibielak, M. (2017). Planning the reconstruction of a historical building by using a fuzzy stochastic network. Automation in Construction, 84, 242-257. https://doi.org/10.1016/j.autcon.2017.08.003

Rakhshani, H., Idoumghar, L., Lepagnot, J., \& Brevilliers, M. (2019). From feature selection to continues optimization. Accepted for EA2019.

Rosłon, J. H., \& Kulejewski, J. E. (2019). A hybrid approach for solving multi-mode resource-constrained project scheduling problem in construction. Open Engineering, 9(1), 7-13. https://doi.org/10.1515/eng-2019-0006

Russell, M. M., Howell, G., Hsiang, S. M., \& Liu, M. (2013). Application of time buffers to construction project task durations. Journal of Construction Engineering and Management, 139(10), 04013008. https://doi.org/10.1061/(ASCE)CO.1943-7862.0000735

Russell, M. M., Hsiang, S. M., Liu, M., \& Wambeke, B. (2014). Causes of time buffer and duration variation in construction project tasks: Comparison of perception to reality. Journal of Construction Engineering and Management, 140(6), 04014016. https://doi.org/10.1061/(ASCE)CO.1943-7862.0000819

Ryall, T., Fitzpatrick, S., Parsloe, R., \& Morris, J. (2012). Collaborative planning on the Borough viaduct project, London. In Proceedings of the Institution of Civil Engineers: Civil Engineering, 165(5), 45-49. https://doi.org/10.1680/cien.11.00015

Shen, Q., Xue, F., Li, Z., Luo, L., Xu, X., \& Sommer, L. (2017). Schedule risk modeling in prefabrication housing production. Journal of Cleaner Production, 153, 692-706. https://doi.org/10.1016/j.jclepro.2016.11.028

Sigalov, K., \& König, M. (2017). Recognition of process patterns for BIM-based construction schedules. Advanced Engineering Informatics, 33, 456-472.

https://doi.org/10.1016/j.aei.2016.12.003

Sinesilassie, E. G., Tabish, S. Z. S., \& Jha, K. N. (2017). Critical factors affecting schedule performance: A case of Ethiopian public construction projects - Engineers' perspective. Engineering, Construction and Architectural Management, 24(5), 757-773. https://doi.org/10.1108/ECAM-03-2016-0062

Siu, M., Lu, M., AbouRizk, S., \& Tidder, V. (2016). Quantitative assessment of budget sufficiency and resource utilization for resource-constrained project schedules. Journal of Construction Engineering and Management, 142(6), 04016003. https://doi.org/10.1061/(ASCE)CO.1943-7862.0001106 
Song, L., Mohamed, Y., \& AbouRizk, S. M. (2009). Early contractor involvement in design and its impact on construction schedule performance. Journal of Management in Engineering, 25(1), 12-20.

https://doi.org/10.1061/(ASCE)0742-597X(2009)25:1(12)

Sonmez, R., Iranagh, M. A., \& Uysal, F. (2016). Critical sequence crashing heuristic for resource-constrained discrete time-cost trade-off problem. Journal of Construction Engineering and Management, 142(3), 04015090.

https://doi.org/10.1061/(ASCE)CO.1943-7862.0001077

Soto Ramírez, D., Rivera Cadavid, L., Orobio Quiñones, A., \& Cuadros López, A. J. (2018). Evaluation of the impact of schedule risks in a road infrastructure project. Espacios, 39(47).

Subramani, T., \& Ammai, A. (2018). Maturing construction management up the BIM model \& scheduling using Primavera. International Journal of Engineering and Technology, 7(3). https://doi.org/10.14419/ijet.v7i3.10.15617

Succar, B. (2009). Building information modelling framework: A research and delivery foundation for industry stakeholders. Automation in Construction, 18(3), 357-375. https://doi.org/10.1016/j.autcon.2008.10.003

Suresh, M., Dutta, P., \& Jain, K. (2011). Analysis of an EPC project: A solution to the resource constrained project scheduling problem using genetic algorithms. International Journal of Industrial and Systems Engineering, 8(2), 251-269. https://doi.org/10.1504/IJISE.2011.041372

Tang, Y., Liu, R., \& Sun, Q. (2014). Schedule control model for linear projects based on linear scheduling method and constraint programming. Automation in Construction, 37, 22-37. https://doi.org/10.1016/j.autcon.2013.09.008

Tesfaye, E., Lemma, T., Berhan, E., \& Beshah, B. (2017). Key project planning processes affecting project success. International Journal for Quality Research, 11(1), 159-172.

Thomas, H. R., Maloney, W. F., Horner, R. M. W., Smith, G. R., Handa, V. K., \& Sanders, S. R. (1990). Modeling construction labor productivity. Journal of Construction Engineering and Management, 116(4), 705-726.

https://doi.org/10.1061/(ASCE)0733-9364(1990)116:4(705)

Tiwari, S., \& Johari, S. (2015). Project scheduling by integration of time cost trade-off and constrained resource scheduling. Journal of The Institution of Engineers (India): Series A, 96(1), 37-46. https://doi.org/10.1007/s40030-014-0099-2

Tomar, A., \& Bansal, V. K. (2019). Scheduling of repetitive construction projects using geographic information systems: an integration of critical path method and line of balance. Asian Journal of Civil Engineering, 20(4), 549-562. https://doi.org/10.1007/s42107-019-00123-3

Tran, D. H., \& Long, L. D. (2018). Project scheduling with time, cost and risk trade-off using adaptive multiple objective differential evolution. Engineering, Construction and Architectural Management, 25(5), 623-638.

https://doi.org/10.1108/ECAM-05-2017-0085

Udaipurwala, A., \& Russell, A. D. (2002). Computer-assisted construction methods knowledge management and selection. Canadian Journal of Civil Engineering, 29(3), 499-516. https://doi.org/10.1139/102-030

Van Eck, N. J., \& Waltman, L. (2011). Text mining and visualization using VOSviewer. ArXiv 2011.

Van Eck, N. J., \& Waltman, L. (2014). Visualizing bibliometric networks. In Measuring Scholarly Impact (pp. 285-320). Springer. https://doi.org/10.1007/978-3-319-10377-8_13

Vidhyasri, R., \& Sivagamasundari, R. (2017). A review on factors influencing construction project scheduling. International Journal of Civil Engineering and Technology, 8(3), 146-157.
Vignesh, C. (2017). A case study of implementing last planner system in Tiruchirappalli District of Tamil Nadu - India. International Journal of Civil Engineering and Technology, 8(4), 1918-1927.

Wambeke, B. W., Hsiang, S. M., \& Liu, M. (2011). Causes of variation in construction project task starting times and duration. Journal of Construction Engineering and Management, 137(9), 663-677.

https://doi.org/10.1061/(ASCE)CO.1943-7862.0000342

Wang, J., \& Yuan, H. (2016). System dynamics approach for investigating the risk effects on schedule delay in infrastructure projects. Journal of Management in Engineering, 33(1), 04016029. https://doi.org/10.1061/(ASCE)ME.1943-5479.0000472

Wang, Y.-R., Yu, C.-Y., \& Chan, H.-H. (2012). Predicting construction cost and schedule success using artificial neural networks ensemble and support vector machines classification models. International Journal of Project Management, 30(4), 470-478. https://doi.org/10.1016/j.ijproman.2011.09.002

Wang, Z., \& Rezazadeh Azar, E. (2019). BIM-based draft schedule generation in reinforced concrete-framed buildings. Construction Innovation, 19(2), 280-294.

https://doi.org/10.1108/CI-11-2018-0094

Xu, X., Wang, J., Li, C. Z., Huang, W., \& Xia, N. (2018). Schedule risk analysis of infrastructure projects: A hybrid dynamic approach. Automation in Construction, 95, 20-34. https://doi.org/10.1016/j.autcon.2018.07.026

Yahya, M. A., \& Mohamad, M. I. (2011). Review on lean principles for rapid construction. Jurnal Teknologi, 54, 1-11. https://doi.org/10.11113/jt.v54.87

Yang, J. (2017). Reviewing construction schedule float management. Open Construction and Building Technology Journal, 11, 1-13. https://doi.org/10.2174/1874836801711010001

Yao, G., Yang, Y., Wang, M., \& Zhou, M. (2018). A review of construction schedule optimization with heuristic method. Journal of Advanced Oxidation Technologies, 21(2).

Zareei, S. (2018). Project scheduling for constructing biogas plant using critical path method. Renewable and Sustainable Energy Reviews, 81, 756-759.

https://doi.org/10.1016/j.rser.2017.08.025

Zhou, J., Love, P. E. D., Wang, X., Teo, K. L., \& Irani, Z. (2013). A review of methods and algorithms for optimizing construction scheduling. Journal of the Operational Research Society, 64(8), 1091-1105. https://doi.org/10.1057/jors.2012.174

Zou, X., Huang, Y., \& Zhang, L. (2016). Genetic algorithm-based method for the deadline problem in repetitive construction projects considering soft logic. Journal of Management in Engineering, 32(4), 04016002.

https://doi.org/10.1061/(ASCE)ME.1943-5479.0000426

Zou, X., Zhang, L., \& Kan, Z. (2014). Improved strategy for resource allocation in repetitive projects considering the learning effect. Journal of Construction Engineering and Management, 140(11), 04014053.

https://doi.org/10.1061/(ASCE)CO.1943-7862.0000896

Zou, X., Zhang, L., \& Qi, J. (2015). A trade-off between time and cost in scheduling repetitive construction projects. Journal of Industrial and Management Optimization, 11(4), 1423-1434. https://doi.org/10.3934/jimo.2015.11.1423

Zwikael, O. (2009). Critical planning processes in construction projects. Construction Innovation, 9(4), 372-387. https://doi.org/10.1108/14714170910995921 